University of Nebraska - Lincoln

DigitalCommons@University of Nebraska - Lincoln

2000

Contracts and Costs in a Corporate/Government System Dynamics Network: A United States Case

\author{
F. Gregory Hayden \\ University of Nebraska-Lincoln, ghayden1@unl.edu \\ Steven R. Bolduc \\ University of Nebraska-Lincoln, BOLDUC@MNSTATE.EDU
}

Follow this and additional works at: https://digitalcommons.unl.edu/econfacpub

Part of the Economics Commons

Hayden, F. Gregory and Bolduc, Steven R., "Contracts and Costs in a Corporate/Government System Dynamics Network: A United States Case" (2000). Economics Department Faculty Publications. 77. https://digitalcommons.unl.edu/econfacpub/77

This Article is brought to you for free and open access by the Economics Department at DigitalCommons@University of Nebraska - Lincoln. It has been accepted for inclusion in Economics Department Faculty Publications by an authorized administrator of DigitalCommons@University of Nebraska - Lincoln. 
Published in Industrial Policies After 2000, edited by Wolfram Elsner and John Groenewegen (Boston/Dordrecht/London: Kluwer Academic Publishers, 2000), pp. 235-284. Copyright @ 2000 Kluwer Academic Publishers.

\title{
Contracts and Costs in a Corporate/Government System Dynamics Network: A United States Case
}

\author{
F. Gregory Hayden and Steven R. Bolduc
}

University of Nebraska-Lincoln

ocial scientists have come to understand that society is a set
of integrated values, beliefs, institutions, technology, and ecological systems as explicitly laid out in Figure 1 (Hayden 1988, 1997). Societal integration and organization takes place through the on-going processing of overlapping institutions and their organizations. The components of transorganizational frameworks, as demonstrated in Figure 1, create and structure the networks within which organizations such as business corporations and government agencies function. "Trans" as used in this sense means across. Across organizational networks normative criteria are provided by social beliefs, technology, and ecological systems (Hayden, 1998). From basic criteria, numerous rules, regulations, and requirements are codified by various institutional organizations such as courts, corporations, and government agencies. Transorganizational frameworks guide multi-organization networks made up of overlapping organizations. Thurman Arnold explained in his Folklore of Capitalism that modern industrial systems are the integration of huge organizations that are coordinated with different kinds of organizations. Corporations, gov- 
ernment agencies, universities, and inter-organizational compacts, for example, function together and are dependent upon each other (Arnold, 1937). They are one of another.

Much of the coordination and planning among the different organizations is finalized through multi-organizational contracts and agreements. Thus, analysis to meet the challenges of industrial policy needs to incorporate the inter-organizational forms whose content, interpretation, and final function are determined by the actions taken in dynamic transorganizational networks. For such an accomplishment, the analytical methodology needs to be transdisciplinary as is implicit in Figure 1.

The purpose here is methodological, substantive, and policyoriented. The purpose is to analyze the ramifications of a cost-plus contract arrangement that is very influential in determining the costs and activities of a particular corporate/government network in the United States. The network is built around the five-state Central Low-Level Radioactive Waste Compact (CIC) to include its policy-making Commission, a number of corporations, and several government agencies. The main methodological concern is how to model a transorganizational network utilizing the knowledge of transdisciplinary models. To accomplish this, the social fabric matrix (Hayden, 1982; Groenewegen, 1988; Meister, 1990) is combined with system dynamics (Radzicki, 1990; Gill, 1996).

Both the social fabric matrix and system dynamics procedures share a similar foundation. Institutional economics is oriented to the development of understandings about system cause and effect or influence patterns. The basic notion is that system management can only proceed upon a sound understanding of this underlying causation. The social fabric matrix is a systematic procedure for identifying and developing system insights. It is in effect, an institutional pattern modeling procedure. It may also serve as a structured process to facilitate the active participation of system players in policy development. System dynamics is another kind of pattern modeling, usually orientated to the quantitative representation of systems for simulation analysis. Qualitative relationships identified through the social fabric matrix process can be translated into a system dynamics model formulation. As a two- part procedure, a prelimi- 


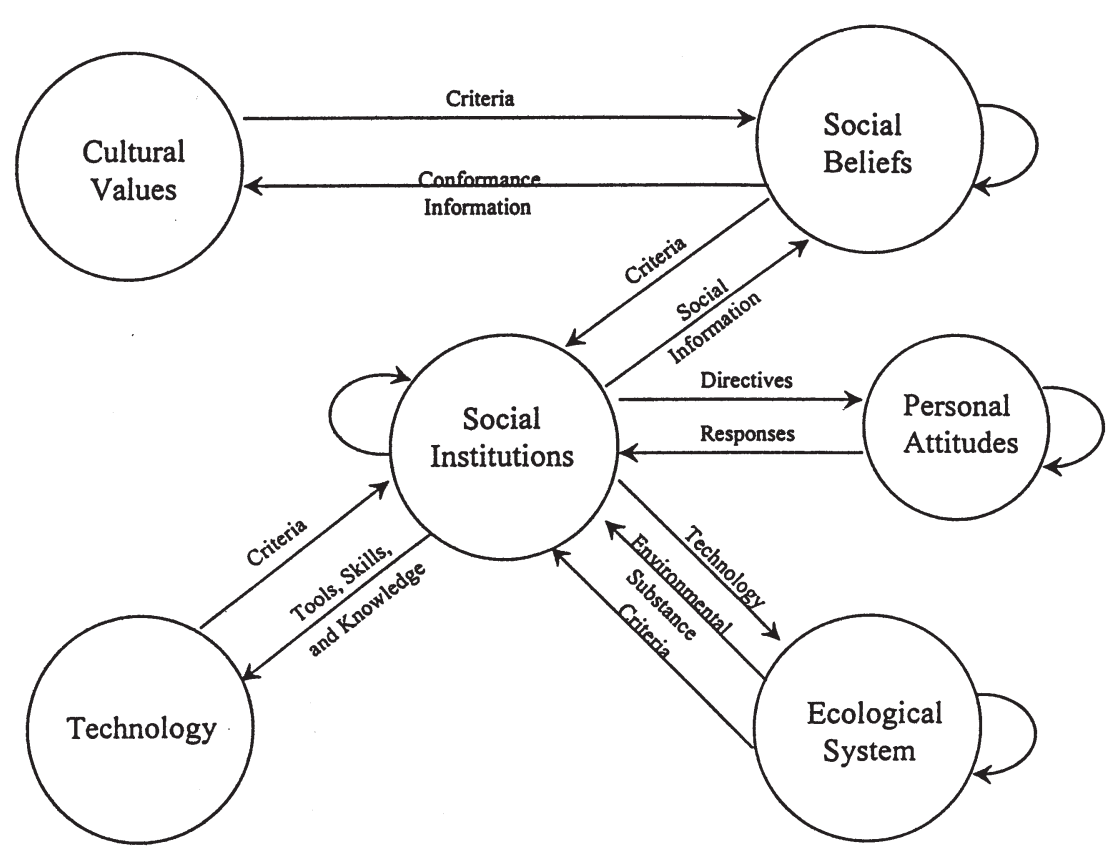

Figure 1. Relationships among values, beliefs, attitudes, technology and the ecological system

nary social fabric matrix is applied to explore systematically the insights of system players and represent them in an entirely qualitative construct. These insights, when translated into a formal system dynamics model, can be manipulated to address the concerns, expectations and ideas of system players and lead toward the development of management strategies and policies with which they have some empathy (Gill, 1996, pp. 179-180). 
The substantive interest is to understand both the network and the monetary costs during the future operational phase of the CIC facility (abbreviations listed at end for the readers' convenience). After a general overview of the system, the analysis is divided between the pre- operational phase and operational phase of the project. Coinciding with the last two years of the pre-operational phase is the construction phase. The latter will be explained with the operational phase cost because that is when construction costs are paid.

In the first section below a standard social fabric matrix (SFM) and digraph are utilized to explain the general context of this case study. The next section is an analysis of the pre-operational phase in which the SFM and digraph are used to demonstrate how to analyze the provisions of a cost-plus contract in order to, first, arrive at algebraic formulae of the contracts and, second, arrive at the total costs to be carried forward into the operational phase. The last section of analysis devoted to the projection of operational costs of the CIC facility. This is accomplished by utilizing the system dynamics program, ithink ${ }^{\circledR}$. The program serves as a vehicle for defining the digraph, and associated SFM, and for projecting an integrated set of operational costs.

Roderic Gill has explained that the SFM is to be constructed through a process of consultations and interactions with realworld system agents and documents (Gill, 1996, p. 173). The analysis here is based on a great deal of personal experience by the authors with the actors and institutions of the network. In addition, numerous primary documents have been consulted. They include the main contracts and agreements, the invoices and accounting systems, meeting minutes, the legal opinions and court decisions, legislative bills, considerable correspondence, the US Security and Exchange Commission (SEC) 10-K reports of the primary corporations, and the Safety Analysis Report (SAR), the name given to a multiple volume application submitted for a license to build and operate the $\mathrm{CIC}$ radioactive waste facility.

Too often, public-policy literature about transorganizations coveys the idea that overlapping organizations are collaborative and cooperative endeavors devoid of animosity. That is misleading with regard to the real world and is not necessary for modeling. In addition, such an assumption is inconsistent with the CIC 
case whose record is one of civil and political turmoil, a continuous parade of lawsuits, expensive overruns, renegotiations and reformulations of contracts, an imprisoned CIC executive director, instances of raw intimidation, exploitative interest expenses on loans, and heavy social and personal burdens on various groups.

\section{Contextual Description of the CIC Network}

Because the corporate/government case of interest revolves around the Central Interstate Low-Level Radioactive Waste Compact (the CIC), a brief history is reviewed before a general overview of the network is presented.

\section{History of Low-Level Waste Compact System}

In 1980, the US Congress passed legislation for states to create a regional decentralized system of compacts for the disposal of low-level radioactive waste. Several basic premises upon which compact legislation were based have proven incorrect. First, contrary to expectations, the stream of low-level radioactive waste generated has continued to decrease since 1980 and is projected to continue to decline. Second, due to the particular characteristics of the externalities associated with federal compacts, they are not structured to be successful for the given objective (Hayden and Bolduc, 1997). Third, the compacts among the states are not regional. For example, California, the most southwestern state bordering the Pacific Ocean, is in a compact with South Dakota and North Dakota, the most northern state bordering Canada. Texas, the most southern state bordering Mexico, is in a compact with Vermont and Maine, the most northeastern state bordering Canada and the Atlantic Ocean. Consequently, the argument that a regional structure of compacts would minimize the number of miles that waste would need to be transported can not be realized.

When little progress was made toward establishing compact relationships and disposal sites. Congress, passed the Low Level 
Waste Policy Amendment Act of 1985. That act generally provided states with a timetable and milestone penalties to encourage each state to either construct its own low-level waste storage facility or form a compact with other states. This was followed by a period of lawsuits in which different states challenged, in some cases successfully, different parts of the federal legislation. After that, internal conflicts within certain compacts led to the resignation or removal of some states. To date, new construction has not been undertaken by any compact.

The CIC is a compact made up of an agreement among the states of Arkansas, Kansas, Oklahoma, Louisiana, and Nebraska. The site selected for the disposal facility is near the northern border of Nebraska, a central state located north of the geographical center of the United States. Louisiana is one of the most southern states, bordering the Gulf of Mexico. Louisiana generates more low-level radioactive waste than any of the other Compact states; therefore, the site location will maximize transportation of such waste for disposal in the CIC area. In addition to the U.S. Congress and state governments, the CIC industrial system includes federal, state, and local government agencies, some of the world's largest and several of the United States' smallest corporations, and the electric generators from the five states.

\section{Social Fabric Matrix Description}

To begin to obtain an understanding of the whole system, the $\mathrm{CIC}$, related agencies and organizations, and their relevant connections are articulated in the social fabric matrix (SFM) in Figure 2. Across the left side and top of the SFM are the social criteria and institutional components, which inform the network digraph that is uniquely associated with the SFM. Researchers utilize the SFM from left to right, so to speak, in order to discover what the row components are delivering to the columnar components in each cell. For cells where there is a delivery, or deliveries, a 1 is entered. The SFM network digraph for Figure 2 is found in Figure 3 with relevant cell deliveries on the directed edges among components. 


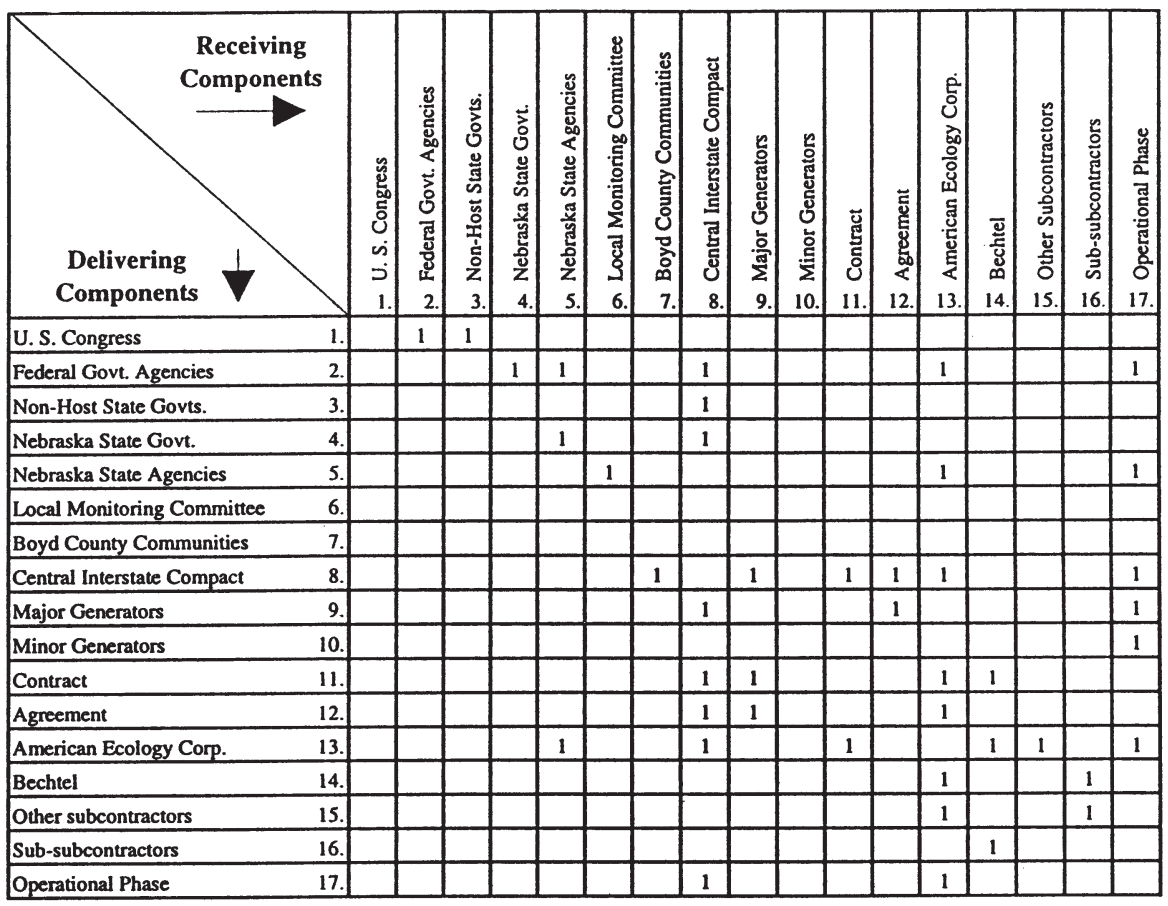

Figure 2. General social fabric matrix of CIC system

Figures 2 and 3 are jointly utilized to provide an overview of the general network for this corporate/government case study. They emphasize the pre-operational phase of the development process with only one entry serving as the subsequent operational phase. A more refined elaboration on both phases will be presented later. The institutional component that created the compact system is the US Congress. To make it function, Congress directly delivered rules, regulations, authority, and responsibilities to federal government agencies and to the five CIC states. Primary responsibility was placed on the US Nuclear Regulatory Commission with concurrent jurisdiction and responsibility residing with the US Environmental Protection Agency, the US Department of Energy, and the US Department of Interior. These federal agencies, in turn, promulgate rules, regulations, requests, and inspec- 


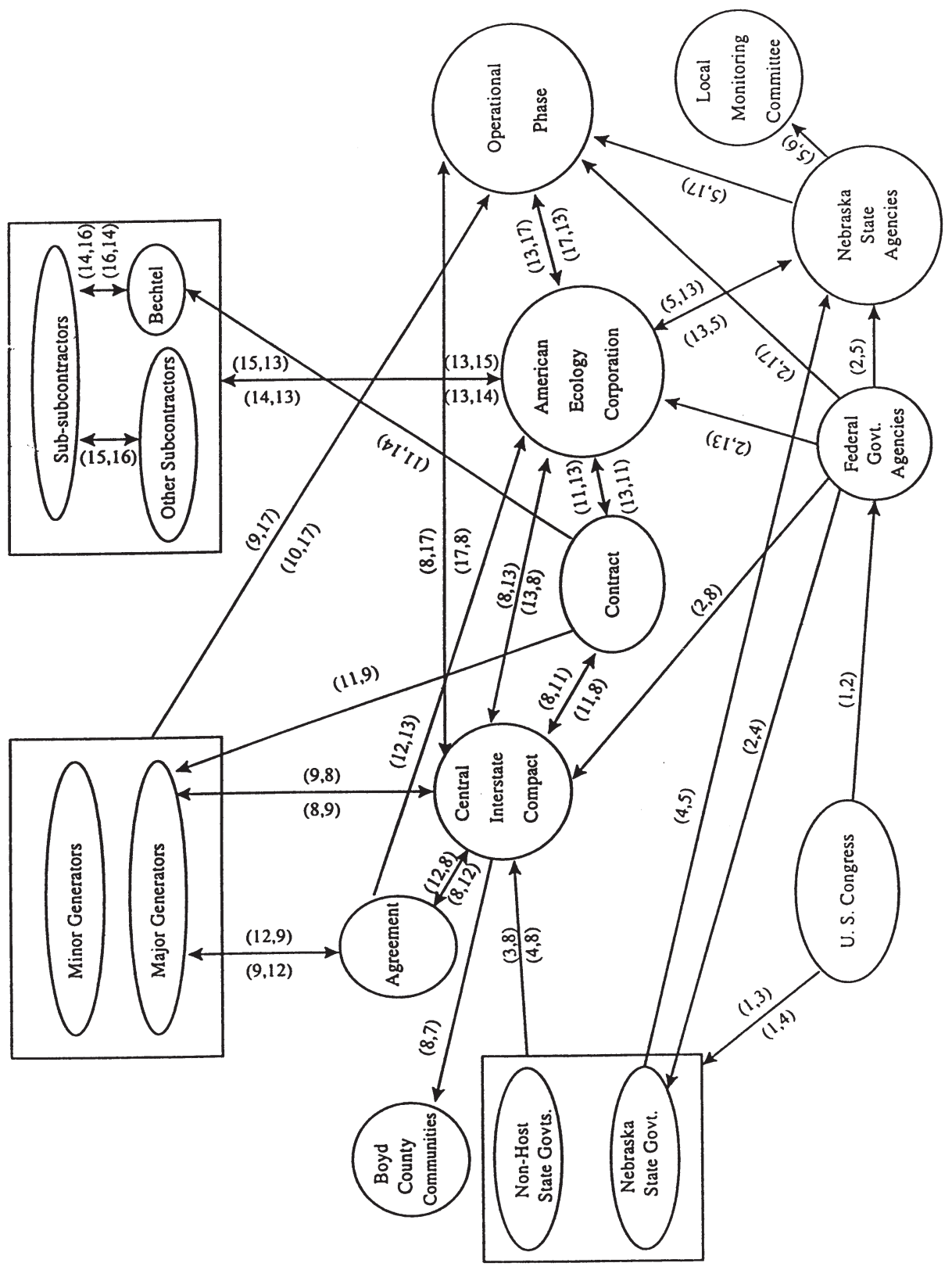

Figure 3. General social fabric digraph network of CIC system. 
tions that are delivered to the CIC states [cell $(2,4)]$; to Nebraska state agencies [cell $(2,5)$ ]; to the CIC [cell $(2,8)]$; and to American Ecology Corporation (AEC) [cell $(2,13)]$. Similar deliveries will be made to the same institutional agencies and organizations during the operational phase of the facility.

The five state governments provide a small percentage of the funds necessary for the administration of the CIC [cells $(3,8)$ and $(4,8)]$. The four states without the site provide $\$ 75,000$ annually to the CIC with the resulting $\$ 300,000$ delivered to Boyd County Communities [cell $(8,7)]$. Boyd County, Nebraska is the proposed site for construction of the low- level radioactive waste disposal facility.

The most powerful organizations in the network are the major generators that own the nuclear power plants in the five states; the most important institutional document is the "Agreement" between the major generators and the CIC. The major generators are Nebraska Public Power Districts, and Omaha Public Power District in Nebraska, Wolfcreek Nuclear Operating Corporation in Kansas, Arkansas Power and Light Co. in Arkansas, and Gulf States Utilities Co. and Louisiana Power and Light Co. in Louisiana. The first two are owned and operated by government, while the latter four are private corporations. The nuclear power plants in Arkansas and Louisiana are owned by Entergy Corporation. Entergy is one of the 250 largest corporations in the United States, operates power generation facilities in several countries, and is currently negotiating to acquire the electric facilities from the British government. Entergy provides leadership among the major generators. The significant influence of the major generators is due to the fact that they provide the funds to the CIC so the CIC can pay AEC for the development of the facility.

The Agreement is a loan agreement between the major generators and the CIC with a stipulation that interest on the loan is to accrue during the pre-operational phase and then be repaid during operations. During the latter period, principal and interest is to be paid to AEC [cell $(17,15)]$ which pays it to the CIC [cell $(13,8)]$ which in turn, pays back the loan principal and interest to the major generators [cell $(8,9)]$. During the operational phase, both the major and minor generators of radioactive waste such as hospitals, research centers, and universities are to deliver waste 
to the disposal facility in Boyd County [cells $(9,17)$ and $(10,17)$ respectively].

In addition to the Agreement, another organizing document in the network is the "Contract" between the CIC and AEC. Both organizations provide provisions and negotiations to the Contract [cells $(8,11)$ and $(13,11)]$ and both are governed by these negotiated provisions [cells $(11,8)$ and $(11,13)]$. The Contract establishes $\mathrm{AEC}$ as the developer and the $\mathrm{CIC}$ as the provider of funds that are obtained by the loan Agreement with the major generators. The funds are then sent to AEC, which in turn, sends most of them to Bechtel National Inc., the subcontractor. The importance of the major generators is also recognized in the Contract even though the generators are not a party to the Contract [cell $(11,9)]$.

A major problem was created when the Contract established $\mathrm{AEC}$ as the developer rather than allow $\mathrm{CIC}$ to remain the developer and itself contracting with AEC to perform particular functions as determined by the CIC. Consequently the CIC is left without research and planning functions, and administrative control. Instead, $\mathrm{AEC}$, the corporation that the CIC hired, determines what is to be accomplished and requests that the CIC give its approval and pay the invoices. Given the provisions of the Agreement and the Contract, the CIC has no alternative because the CIC does not have the millions of dollars to hire planners, engineering firms, test well drillers, monitors, and so forth to inspect and evaluate the developer's work.

A connection not recognized by the Contract is a connection to the Nebraska State agencies that have been granted authority to license and regulate the development and operation of the facility by the Nuclear Regulatory Commission and by the Nebraska state government. The lead state regulatory agency is the Nebraska Department of Environmental Quality (NDEQ). Since it is not a signatory to the Contract, the Contract has established provisions that NDEQ has not approved, nor will approve, in the operational phase [cell $(15,17)]$. This arrangement has led to conflict and lawsuits, and will continue to do so in the future.

An odd arrangement is the establishment of NDEQ as a subcontractor to AEC. Thus, NDEQ is dependent on the corporation it is mandated to license and regulate for the funds necessary to under- 
take the licensing and regulation activities. NDEQ will continue to perform licensure and regulation functions during the operational phase [cell $(5,17)]$. In addition, NDEQ will regulate the volume rates that AEC can charge on waste deposited at the facility.

The payments to NDEQ for reimbursable costs [cell $(13,5)]$ that are provided by AEC, are also obtained from the major generators through the CIC. Included each year in the invoices from NDEQ to AEC is $\$ 100,000$ for the Local Monitoring Committee (LMC) in Boyd County [cell $(5,6)]$. These funds are provided, according to legislation, so that the LMC can monitor all aspects of the system. Such monitoring activities have included research, data collection, advocacy, lawsuits, attendance at meetings, lobbying of legislation, and so forth. LMCs information is delivered to all organizations in the system. These informational deliveries are not shown in Figure 2 and 9.3 because the main interest here is the cost aspects of the system.

The network recipient of the most funds is Bechtel National, Inc. Approximately 80 percent of the $\$ 81$ million that has been expended to date on the project has gone to Bechtel, one of the world's largest engineering services and construction corporations. According to Laton McCartney in Friends in High Places, Bechtel prefers a contractual arrangement whereby a smaller firm serves as the main contractor that actually signs the contract for development and construction, and Bechtel establishes a subcontract with the smaller firm to do the work and receive most of the money. That is consistent with the arrangement Bechtel has in the CIC network. AEC, a small corporation in desperate financial condition, has a "Technical Services Agreement" with Bechtel with the latter to do the planning, engineering design, and construction of the CIC facility. The Technical Services Agreement [11,14], is recognized by the Contract between AEC and the CIC.

This SFM description clarifies that it is not possible to understand any part of the system without knowing the contextual environment in which the system exists. While remaining cognizant of the surrounding network, the following sections will further refine and elaborate particular parts of the system with a final goal of projecting costs of operating the facility. 


\section{Pre-operational Phase Expenses Without Construction Costs}

Although the main interest of this chapter is to model the costs during the thirty-year operational phase of the CIC facility, the network of the pre-operational phase costs are also visited because costs will be carried over to the operational phase from the activities of the pre-operational phase. The costs are to be amortized and repaid from disposal charges assessed on users of the storage facility during the operational phase.

As defined in this section, the pre-operational phase of the CIC project includes all activities prior to the beginning of facility operation with the exception of facility construction (construction payments are not incurred until the operational phase). In preparation for planning discussions regarding future litigation and budgets, AEC presented a projected schedule of the licensing and development process to the CIC. The projected date for commencement of operations, approximately January 2002, assumed that NDEQs schedule of license application evaluation is maintained and results in application approval (1997 Pre- construction Plan 2.0, 1996). Thus, the pre-operational phase is from 1987 through December 2001. The SFM and accompanying digraph in Figures 9.4 and 9.5 are used to analyze contracts to determine cost functions. Although the SFM of Figure 4 is devoted to the pre- operational phase, the operational phase (row and column 20) is included as a component because it receives accumulated costs from the pre-operational phase as well as from the construction phase. The main contracts of concern are the Contract between AEC and the CIC, and the Agreement between the major electric generators of the five states and the CIC.

\section{SFM of Contract between AEC and the CIC}

The Contract consists of the Contract itself, signed in 1987, and three subsequent amendments. Since it is the main determinant of costs and distribution of funds among parties of the CIC process, an in-depth analysis of the Contract is needed. But how? What kind? Attorneys analyze contracts for conformity to law. Contractors and subcontractors are only concerned about the costs they are allowed 


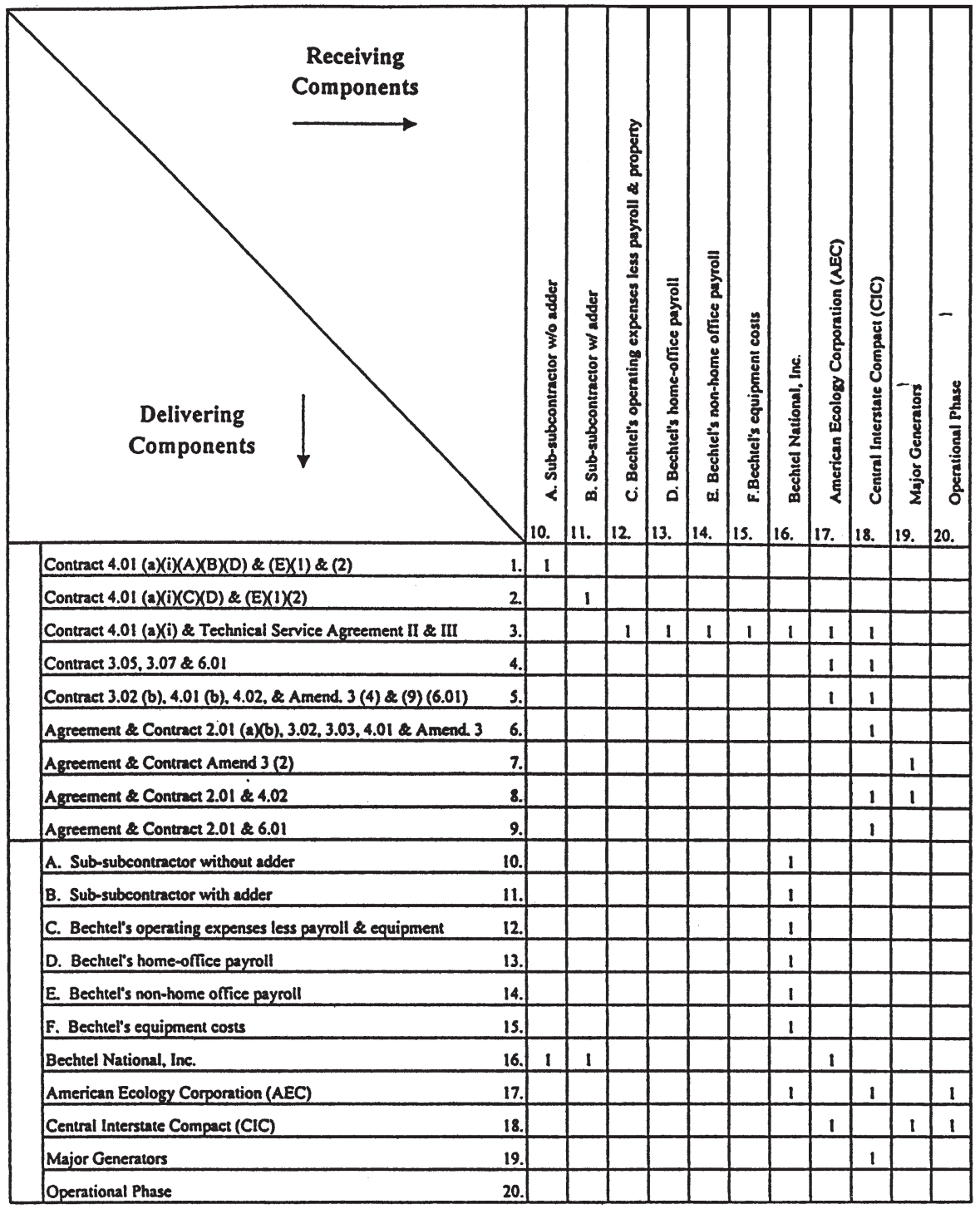

Figure 4. Social fabric matrix of contracts and costs during CIC pre-operational phase 


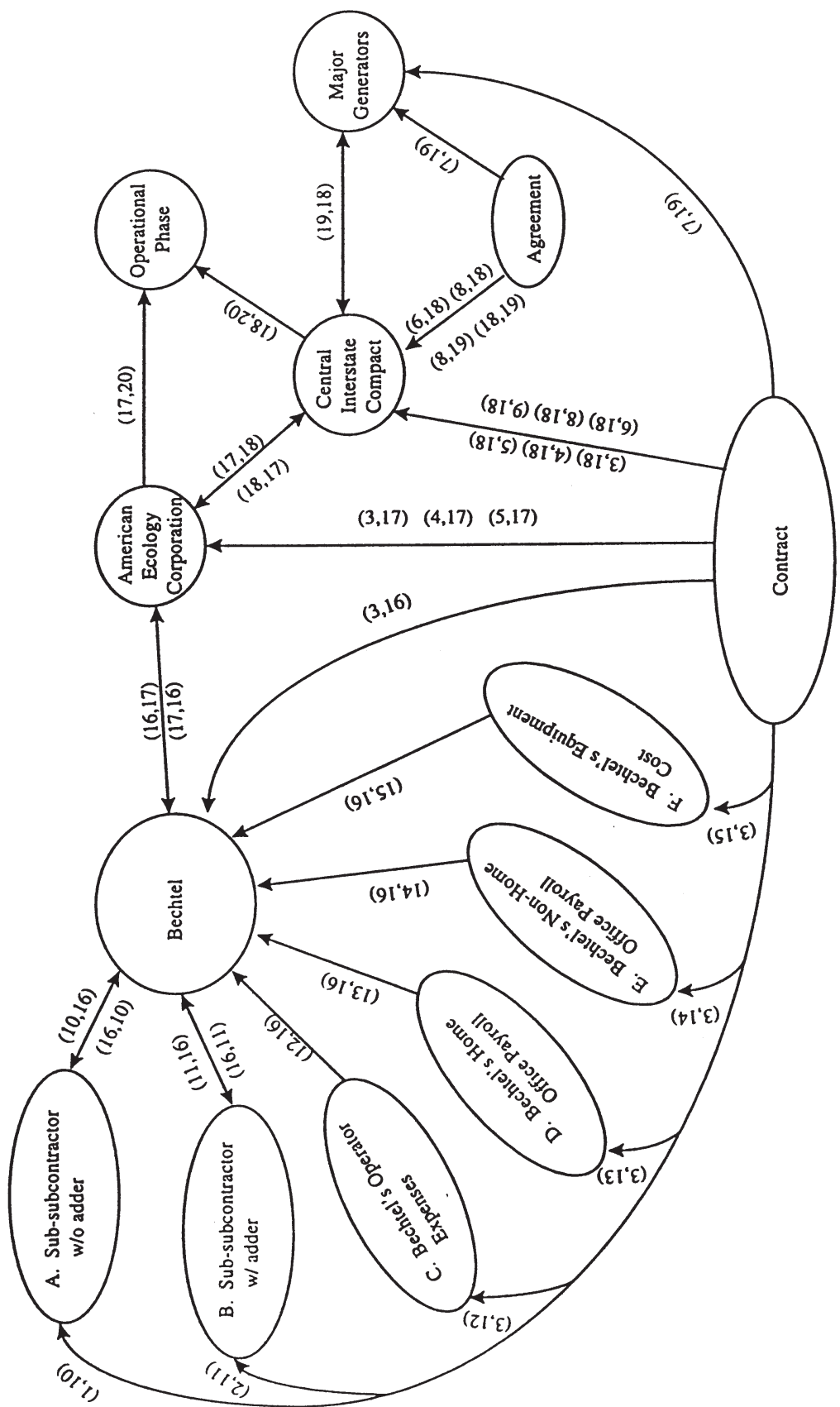

Figure 5. Social matrix digraph network of contracts and costs during CIC pre-operational phase 
in the part of the contract directly affecting them. Economists seldom read contracts; rather they do statistical studies on the ex-post financial flows. How do we get an ex-ante analysis of consequences? As is usually the case, the Contract's text does not contain mathematical or arithmetic expressions. Can we translate the textual provisions into the mathematical expressions helpful for analysis? Although such analysis has not been done before, a SFM analysis is completed in order to discover how different contract articles, sections, and terms define costs; what criteria are provided regarding cost criteria and requirements; and how the Contract defines the relevant relationships among different parties.

The SFM requires researchers to move cell by cell and identify whether there are deliveries in the cells in order to provide an explication of those deliveries. In some cases, the conversion of cellular information to a mathematical expression allows for more precision in explaining a particular delivery. To use the SFM, the Contract is thoroughly analyzed to discover the major criteria, requirements, and institutions. As discovered, they are entered in the SFM as the row and column components. Then, the SFM is used to explain what each row component delivered to each column component as relevant to our problem area.

Social belief criteria are expressed through the rules, regulations, and requirements of the Contract. These criteria are expressed in the matrix (Figure 4) as the sections in the Contract from whence they gain their legitimacy. For example, Article 4.01 in Figure 4 indicates that the criterion is found in Article 4, Section 1, of the Contract. The social institutions in Figure 4 are those recognized in the Contract. They include corporations such, as AEC and Bechtel, accounting categories such as subcontractors' costs, and so forth. In comparing Figure 4 with Figure 2, it becomes evident that the SFM components in Figure 4 are refined subdivisions of the Contract and Agreement components of the SFM in Figure 2.

A complete SFM of the Contract and Agreement is not included in Figure 4 for a number of reasons. First, our main interest is in the operational phase. Second, receiving columns 1 through 9 are excluded because they demonstrate inter-contractual legal deliveries not immediately pertinent to the cost analysis. Symbols A through F designate both the category of the contractor and the in- 
voice expenses of the same contractor. For example, A is the expenses on the invoice of a sub-subcontractor A sent to Bechtel. The components and cellular information included are sufficient to explain how formulae (1), (2), and (3) below can be derived from the SFM. Figures 9.4 and 9.5 are limited to defining Bechtel's part of the cost-plus formula. By explaining that part of the SFM, we learn how the cost-plus adder clauses build through the Contract process to define formulae (1), (2) and (3). Cost categories $G$ through $\mathrm{N}$ (see Table 1) are here excluded because the inclusion of cost categories A through $\mathrm{F}$ for Bechtel are sufficient for demonstrating how the analysis can be completed for contractual provisions. This is done through understanding the cellular deliveries as follows:

Cell $(1,10)$ Contract's Delivery to A: The delivery of interest in cell $(1,10)$ for defining costs is the coefficient delivered to sub-subcontractor A from the Contract. That coefficient is the coefficient that may be used to multiply costs before sending the invoice to Bechtel for reimbursement. A is the expenses of a sub-subcontractor whose contract with Bechtel does not allow for a cost plus adder, thus, the coefficient delivered in cell $(1,10)$ is 1 .

Cell $(2,11)$ Contract's Delivery to B: The Contract terms in row 2 of the SFM are delivered to B. B is the expenses of a sub-subcontractor who may add 10 percent to its cost before sending its invoice to Bechtel. Thus the coefficient delivered in cell $(2,11)$ is $(1+.10)$.

Cell $(3,12)$ Contract and Technical Service Agreement's Delivery to C: The CIC/AEC Contract and the Technical Service Agreement between AEC and Bechtel join together to determine the relevant delivery in this cell. $\mathrm{C}$ is Bechtel's own operating expenses, exclusive of payroll expenses and capital equipment costs that are delivered internally to Bechtel. The Contract delivers a coefficient of $(1+.10)$, thus, the $C$ expenses on the invoice can be increased by 10 percent.

Cell $(3,13)$ Contract and Technical Service Agreement's Delivery to D: D is Bechtel's home-office payroll expenses for the project. Due to contractual deliveries, they are increased by about 41.5 percent, and in turn, 78 percent of that total is added for a coefficient of $(1+.415)[1+.78]$. 
Table 1. Cost-plus percentages that multiply CIC costs

\begin{tabular}{|c|c|}
\hline Percentage & Definition of Terms \\
\hline $\mathrm{PV}=110 \%$ of $\mathrm{A}$ & $\begin{array}{l}\text { A is cost of sub-subcontractors without cost-plus } \\
\text { contract }\end{array}$ \\
\hline$+121 \%$ of $B$ & $\begin{array}{l}\mathrm{B} \text { is costs of sub-subcontractor with cost-plus con- } \\
\text { tract adder equal to } 10 \%\end{array}$ \\
\hline$+116 \%$ of $C$ & $\begin{array}{l}\mathrm{C} \text { is Bechtel's operating expenses, exclusive of pay- } \\
\text { roll \& capital costs }\end{array}$ \\
\hline$+291 \%$ of D & D is Bechtel's home office payroll \\
\hline$+233 \%$ of $E$ & E is Bechtel's non-home office payroll \\
\hline$+116 \%$ of $F$ & F is Bechtel's capital equipment bought by CIC \\
\hline$+\mathrm{G}$ & $\begin{array}{l}\text { G is stipulated sum or unit cost contract awarded by } \\
\text { Nebraska DEQ }\end{array}$ \\
\hline$+(1+a)$ of $\mathrm{H}$ & $\mathrm{H}$ is cost-plus contracts awarded by Nebraska DEQ \\
\hline+ DEQ & DEQ is in-house costs of Nebraska DEQ \\
\hline$+105 \%$ of $I$ & $\begin{array}{l}\text { I is stipulated sum or unit-cost contract awarded by } \\
\text { DEQ }\end{array}$ \\
\hline$+108 \%$ of $\mathrm{J}$ & $\begin{array}{l}\mathrm{J} \text { is AEC's operating expenses exclusive of payroll } \\
\text { and equipment costs }\end{array}$ \\
\hline$+258 \%$ of $\mathrm{K}$ & $\mathrm{K}$ is AEC's home office payroll \\
\hline$+210 \%$ of $L$ & L is AEC's non-home office payroll \\
\hline$+108 \%$ of $\mathrm{M}$ & $\mathrm{M}$ is AEC capital equipment bought by CIC \\
\hline$+\mathrm{N}$ & $\begin{array}{l}\mathrm{N} \text { is lobbying and extraordinary legal expenses of } \\
\text { AEC }\end{array}$ \\
\hline
\end{tabular}


Cell $(3,14)$ Contract and Technical Service Agreement's Delivery to E: $\mathrm{E}$ is Bechtel's non-home office payroll expenses for wages and salaries. The contractual delivery is $(1 .+.415)[1+$ .425] whereby $\mathrm{E}$ is increased by 41.5 percent, and that total is increased by 42.5 percent.

Cell $(3,15)$ Contract and Technical Services Agreement's Delivery to F: The coefficient delivered in Cell $(3,15)$ is one which is to be applied to F. F is capital equipment that is bought by the subcontractor, Bechtel, who selects the equipment and owns it.

Cells $(10,16$ and 11,16) Sub-subcontractors Deliveries to Bechtel: The sub-subcontractor's expenses, multiplied by the contractual coefficients delivered to them (as explained above), are delivered as invoices to Bechtel. They are, therefore, A and B $(1+.10)$ when delivered.

Cells $(12,16),(13,16),(14,16)$, and $(15,16)$ Bechtel's Internal Cost Categories Deliveries to Bechtel: Bechtel's own expenses are delivered to Bechtel with their coefficients as defined above. They are: $\mathrm{C}(1+.10),[\mathrm{D}(1+.415)][1+.78],[\mathrm{E}(1+.415)][1+.425]$, and F.

Cell $(3,16)$ Contract and Technical Service Agreement's Delivery to Bechtel: Cell $(3,16)$ provides the contractual authority for Bechtel to apply the coefficient $(1+.05)$ to invoices it receives from sub-subcontractors A and B, and $(1+.08)$ to its own internal expenses as they are bundled and presented with their own internal coefficients as presented in the cellular explanation just preceding this one.

Cell $(3,17)$ Contract and Technical Service Agreement's Delivery to AEC: Cell $(3,17)$ delivers to AEC the coefficients to apply to invoices received from subcontractors such as Bechtel. The nonfactual authority is provided for AEC to multiply subcontractor's invoices by $(1+.05)$ and to multiply its own expenses by $(1+$ $.08)$.

Cell $(16,17)$ Bechtel Delivery to AEC: Given the authority explained above to utilize the contractually defined cost-plus coefficients, Bechtel sends an invoice to AEC as follows: $\{\mathrm{A}+[\mathrm{B}(1$ $+.10)]\}\{1+.05\}+[\mathrm{C}(1+.10)]+\{[\mathrm{D}(1+.415)][1+.78]+[\mathrm{E}(1+$ $.415)][1+.425]\}\{1+.10\}+\mathrm{F}(1+.10)$

The aggregating character of the Contract becomes clear with some very large cost-plus adders being authorized, often with- 
out a rational economic explanation. $\mathrm{D}$, for example, is increased by 41.5 percent and that total increases by another 78 percent, as was explained above. That total, with adders, is increased again by 10 percent before sending the invoice to AEC. $\mathrm{E}$ is treated similarly. $\mathrm{F}$ is an equipment gift to Bechtel, ultimately paid for by the CIC. Bechtel selects the equipment, gets to own it, and in addition adds 10 percent onto the cost of the gift.

Cell $(3,18)$ Contract and Technical Services Agreement Delivery to the CIC: Cell $(3,18)$ establishes the authority for the cost-plus invoices to be submitted to the CIC for reimbursement.

Cell $(17,18)$ AEC Delivery to the CIC: With regard to the Bechtel part of the cost-plus process, AEC takes the invoices sent form Bechtel, adds another 5 percent of that total, as provided in cell $(3,16)$, and sends the total invoice to the CIC for reimbursement. Thus, the Bechtel part of the formula becomes: $\{\{\mathrm{A}+[\mathrm{B}(1+.10)]\}$ $\{1+.05\}\}\{1+.05\}+[\mathrm{C}(1+.10)][1+.05]+\{\{[\mathrm{D}(1+.415)][1+.78]+$ $[\mathrm{E}(1+.415)][(1+.425]\}\{1+.10\}\}\{1+.05\}+[\mathrm{F}(1+.10)][1+.05]$

As clarified in the discussion of cell $(3,16)$, AEC may also add a 5 percent adder to the costs of other subcontractors as well as add an 8 percent adder to AECs own expenses. Therefore, the total invoice, PV, sent to the CIC is as found in formula (1).

$$
\begin{aligned}
\mathrm{PV}= & \{\mathrm{A}+\mathrm{B}(1+.10)]\}\{1+.05\}\}\{1+.05\}+[\mathrm{C}(1+.10)][1+.05] \\
& +\{\{\mathrm{D}(1+.415)][1+.78]+[\mathrm{E}(1+.415)][1+.425]\}\{1+.10\}\} \\
& \{1+.05\}+[\mathrm{F}(1+.10)][1+.05]+\mathrm{G}+[\mathrm{H}(1+\mathrm{a})]+\mathrm{DEQ} \\
& +[\mathrm{I}(1+.08)]+\{\mathrm{JJ}(1+.365)][1+.75]+[\mathrm{K}(1+.365)] \\
& {[1+.425]\}\{1+.08\}+[\mathrm{L}(1+.08)]+\mathrm{M}+\mathrm{N} }
\end{aligned}
$$

PV stands for the present value of the invoices sent to the CIC. In addition to the Bechtel part of the formula contained in Figure 4, all contractors, subcontractors and sub-subcontractors are included (symbols $\mathrm{G}$ through $\mathrm{N}$ are defined in Table 1 ). When the formula is solved, the percentage coefficient for each term is as found in Table 1.

Examples from Table 1 can be used to indicate why the costs of the project have become so exorbitant and why cost overruns have been common. For example, sub-subcontractors a not allowed a cost-plus adder, yet their costs. A, invoiced to the CIC are 110 percent of costs because Bechtel and AEC are allowed to include their own percentage adders. Bechtel's home office 
payroll, D, is invoiced at 291 percent of cost, their non-home office payroll by 233 percent, and so forth. The information in formula (1) and Table 1 also clarifies that all incentives are in the Contract are to increase cost functions without disincentives or penalties for increasing cost functions. The Bechtel part of formula (1) has the highest cost adders and it is also the part that has received the most payments from the CIC, to date about 80 percent of approximately $\$ 81$ million. Table 2 is an example of how a $\$ 1,000,000$ budget of direct costs becomes a budget of $\$ 2,269,850.63$ when all adders, summing to $\$ 1,269,850.63$, are added as defined by formula (1).

Cells $(6,18),(7,19),(8,18)$ and $(8,19)$ Contract and Agreement Deliveries to the CIC and Major Generators: The Agreement between the CIC and the major electric generators in the five states of the CIC establishes the authority for the major generators to provide the financing source for the projects expenses. This Agreement is also recognized in the Contract, giving AEC the authority to submit invoices and expect the financing from the major generators for the paying the invoices. The major generators agreed to finance the amount of the invoices submitted to the CIC from AEC. Thus, the costs are really being financed by the electric ratepayers. The interest rate delivered by the Agreement to the major generators is the prime rate in the United States plus 6.5 percent. The financing is an accrued interest arrangement whereby interest accumulates and the interest rate is applied to the accruing interest as well as to the principal. When the facility begins operations, the loan plus accrued interest will be amortized for repayment as part of the charges to those depositing radioactive waste at the facility.

Cell $(18,19)$ The CIC Delivery to Major Generators: Cell $(18,19)$ is the delivery of notice from the CIC to the major electric generator to send a financial sum equal to the invoiced expenses that have been submitted from AEC for reimbursement.

Cell $(19,18)$ Major Generators Delivery to the CIC: The delivery in cell $(19,18)$ is the delivery of loanable funds from the generators to the CIC to pay AEC's invoices.

Cells $(19,17),(17,16),(16,11)$ and $(16,10)$ : Delivery of Payments to Pay Invoices of AEC, Bechtel, A and B: The cells are the mone- 


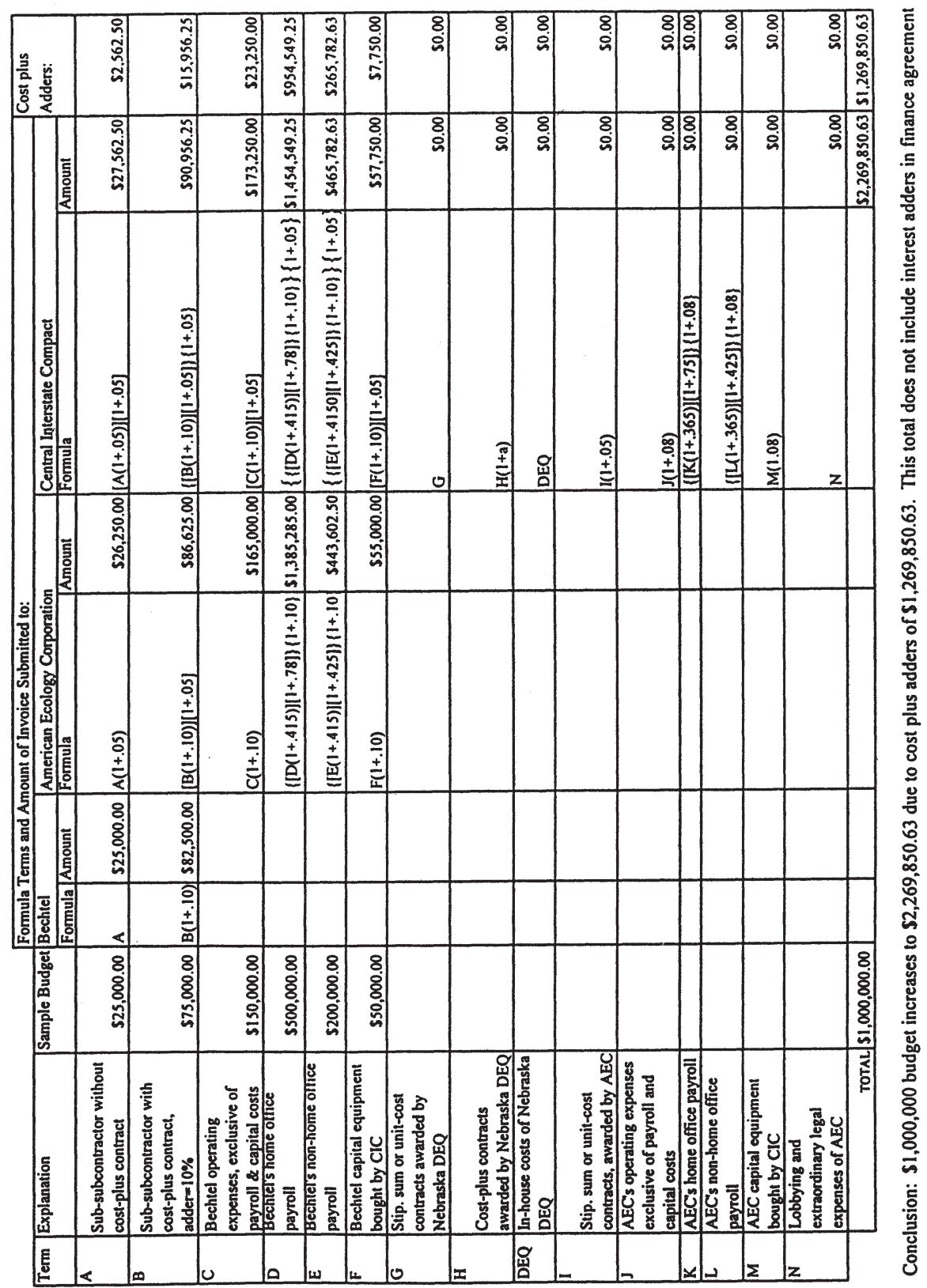

Table 2. Example of direct costs equal to $\$ 1,000,000$ to demonstrate Bechtel part of formula 
tary payment flows for reimbursement of invoices as the money is loaned by the major generators to the CIC which pays AEC who pays Bechtel who pays sub-subcontractors.

Cell $(18,20)$ The CIC Delivery to Operational Phase: Cell $(18,20)$ is the delivery of formula (2) to the facility operational phase of the CIC for amortization of the financing from the major generators. Formula (2) is as follows:

$$
\mathrm{FV}=\sum_{\mathrm{j}=1987}^{\mathrm{y}} P \mathrm{~V}_{\mathrm{j}}(1+\mathrm{r}+.065)^{\mathrm{y}-1}
$$

$\mathrm{FV}$ is the future value of the financing from the major generators. The letter $\mathrm{j}$ indexes the year in which the PV on the invoice was paid; the first year being 1987. The letter $y$ is the year to which the loan is being accumulated; the last year being 2001. $\mathrm{PV}_{\mathrm{j}}$ is the total value of major generator financing to pay costs in year $j$. The prime interest rate is $r$, and .065 is the interest rate added to the prime rate as specified in the Agreement. The estimated total owed to the major generators at the end of 1996 was approximately \$120 million; this includes the amount of the loan and the accrued interest for the period 1987-1996 (Hayden and Snider, 1996). The accumulation is not only significant but continues to grow exponentially. It will continue to grow in this fashion until the facility begins operation in January 2002. To find that amount, the total owed was projected forward, at the same rate as it has increased from 1987 through 1996, to December 2001. The total delivered in cell $(18,20)$ is to be amortized and paid in the operational phase. It is projected to be approximately $\$ 325$ million at the end of 2001.

Cell $(5,17)$ and $(5,18)$, Contract Delivery to AEC and the CIC: Provisions in the Contract between AEC and the CIC provide that in the initial period of the contract, a small part of project costs are financed by AEC. The Contract delivers those provisions in cells $(5,17)$ and $(5,18)$. From 1987 to 1992 that financing contribution amounted to about $\$ 6.2$ million.

Cell $(\mathbf{1 7}, 20)$ AEC Delivery to Operational Phase: Between 1987 and 1992 the contribution from AEC for financing pre-operational cost amounted to about $\$ 6.2$ million. Both the CIC and 
AEC have responsibilities in the collection of the loan plus accrued interest in the operational phase of the facility. Together they deliver the results of formula (3), as follows:

$$
\mathrm{FV}_{\mathrm{AEC}}=\sum_{\mathrm{j}=1987}^{\mathrm{y}} \operatorname{AECPV}_{\mathrm{j}}(1+.20)^{\mathrm{y}-\mathrm{j}}
$$

where $\mathrm{FV}_{\mathrm{AEC}}$ is the future value of the financing from $\mathrm{AEC}$ to include accrued interest; $j$ is the year in which AECPV was contributed, first year being 1987; and y is the year to which the loan is being accumulated. AECPV is the total value of financing contributed to pay costs in year $j$, and .20 is the interest rate paid on AEC financing until January 1997. According to the CIC correspondence, the total of principal plus accrued interest in December 1996 was \$21,427, 401. Beginning in January 1997, that amount has been carried forward using the new interest rates for an expected amount to be owed to AEC in December 2001 equal to approximately \$33.4 million. That amount is delivered to the operational phase for amortization and repayment from operational revenues.

The SMF has provided a means to describe the general context, to articulate particular socioeconomic components embedded in that context, to define connections among the components, and to convert cellular information to mathematical expression where appropriate. The analysis completed above allows us to see how the cost-plus formula builds through the Contract and Agreement to create a financial burden to be carried forward to be amortized and paid during the operational phase. The total delivered to the operational phase is about $\$ 504.1$ million. It includes the major generator financing (\$325 million), AEC financing contribution (\$33.4 million), construction loan (\$91.6 million), financial assurance loan (\$41.5 million) and AECs subsidiaries' interest (\$12.6 million). Major generator financing and AEC financing were explained above. The others will be explained below. In addition, the analysis above pinpoints the particular provisions in the Contract and Agreement that need to be renegotiated to reduce the financial burden. 


\section{Operational Phase}

According to Pre-construction Plan 2.0, developed for the CIC by AEC and Bechtel, the operational phase of the facility is planned to begin on January 2002, assuming the NDEQ licensing process is followed, and the license is granted. Again, the plan is for the facility to operate from 2002 to 2031. The purpose of this section is to estimate the allowable yearly costs during the operational phase in order to determine the consequent fee that waste generators will need to pay for waste storage. As explained earlier, some costs accrued in the pre-operational phase are to be amortized and paid during the operational phase. The cost of facility construction, which occurs the two years prior to operations commencing, is also amortized to be paid by storage fees. Moreover, since $\$ 4.5$ million in funds for re-mediation and possible early closure of the facility are to be in place the day operations begin, that amount is also to be borrowed. According to the SAR this loan of financial assurance funds will be amortized according to the same parameters as the construction loan.

To discover the corporate/government network that processes these costs, a SFM of the institutions involved is constructed in Figure 6. Because the delivery of contractual provisions has already been explained and demonstrated in the pre-operational SFM of Figure 4, this SFM does not include the contractual criteria, rules, and requirements found in the Contract, Agreement, and SAR. The SFM will be reported, modeled and, analyzed with the assistance of the system dynamics program, ithink. The SFM network digraph will be the system dynamics format of the ithink program.

\section{System Dynamics Network and Analysis}

System dynamics is an intellectual evolution from systems theory (Hayden, 1989). Crucial to dynamic modeling is an understanding that the behavior of a system depends on its structure and the connections among the parts. A fundamental concept is that systems are structured so that the system provides for what 


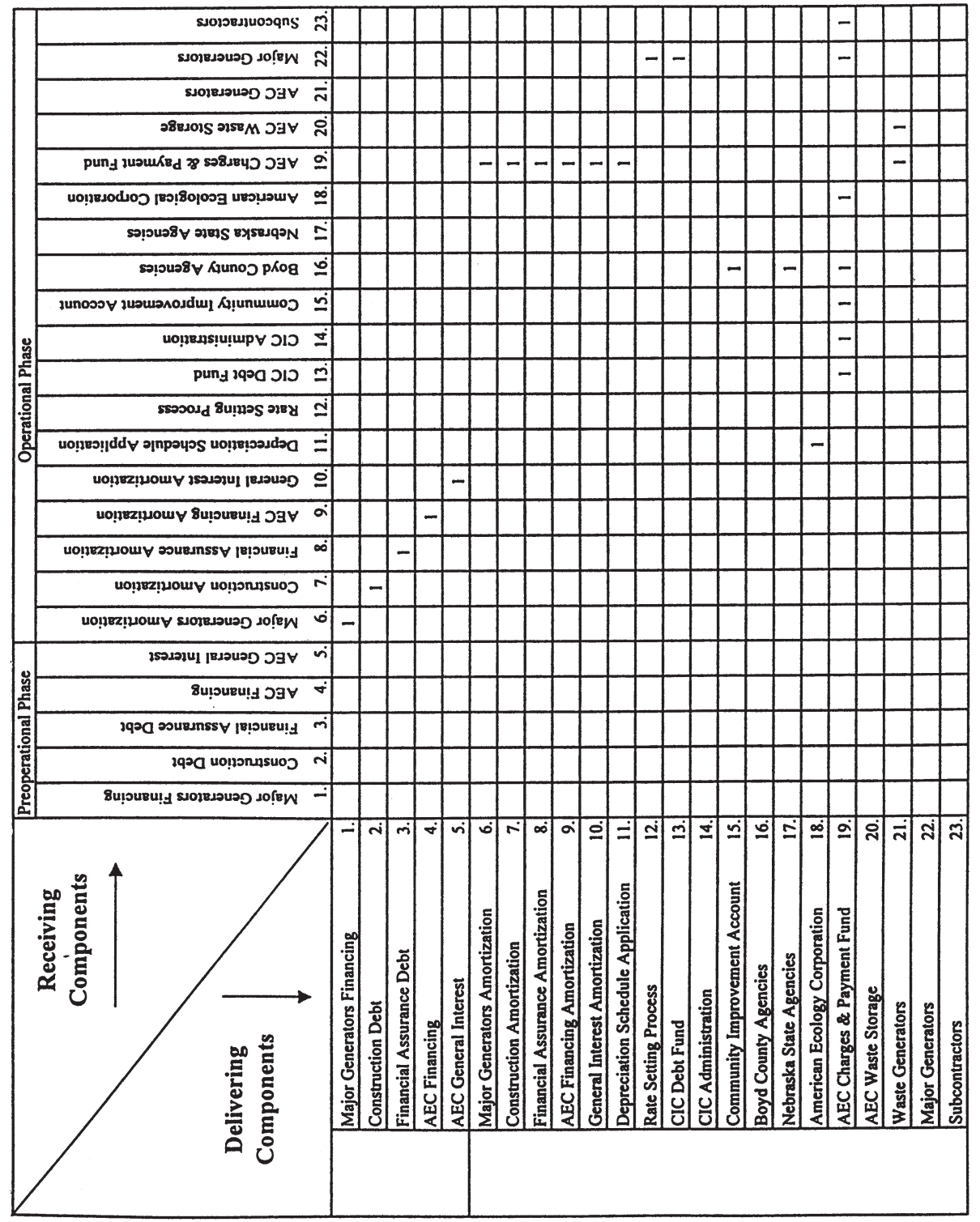

Figure 6. Social fabric matrix of institutional components during CIC operational phase 
is called feedback among the component parts. This means that one component influences another component, which influences another component, maybe in another part of the system, which in turn influences the original component (Radzicki and Sterman, 1994). Such "feedback" patterns are emphasized in system dynamics. "System dynamics models represent change as a function of the interplay between underlying patterns of positive- and negative-polarity feedback" (Gill 1996, p. 168). Negative feedback guides systems to stability and sustainability while positive feedback leads to growth and decay.

Several system dynamic programs have been developed. The authors, however, have found the modeling capabilities of ithink to be the most consistent with the theories and process concepts of the social sciences and institutional economics. In the explanation and diagrams below, circles are rules, regulations, requirements, or criteria-those expressions of social beliefs. The circles with "spigots" are the regulations, or regulators, that either regulate the level of deliveries between institutions or deliver regulations to influence other regulations. The rectangles are the SFM institutional components from Figure 6. The directed double lines represent the delivery flows among institutions, and the single-line directed arcs represent deliveries of rules, regulations, requirements, and criteria for the regulation of flows among institutions. The cloud-looking symbols are utilized to indicate that the source or destination of a delivery is not being explained by this model. (The symbols are in Appendix D).

\section{Operational Phase Network}

The analytic approach begins by presenting the highest level framework and proceeds to explanation and analysis of the particular sections which are the working parts of the whole. The high level, found in Figure 7 presents the main sections, or sectors, of the problem of concern. They are the Waste Generators, the CIC, AEC (divided between the production operation in Boyd County and the pecuniary operation of the corporation), subcontractors to the AEC, Boyd County Agencies, and Nebraska State Agencies. 


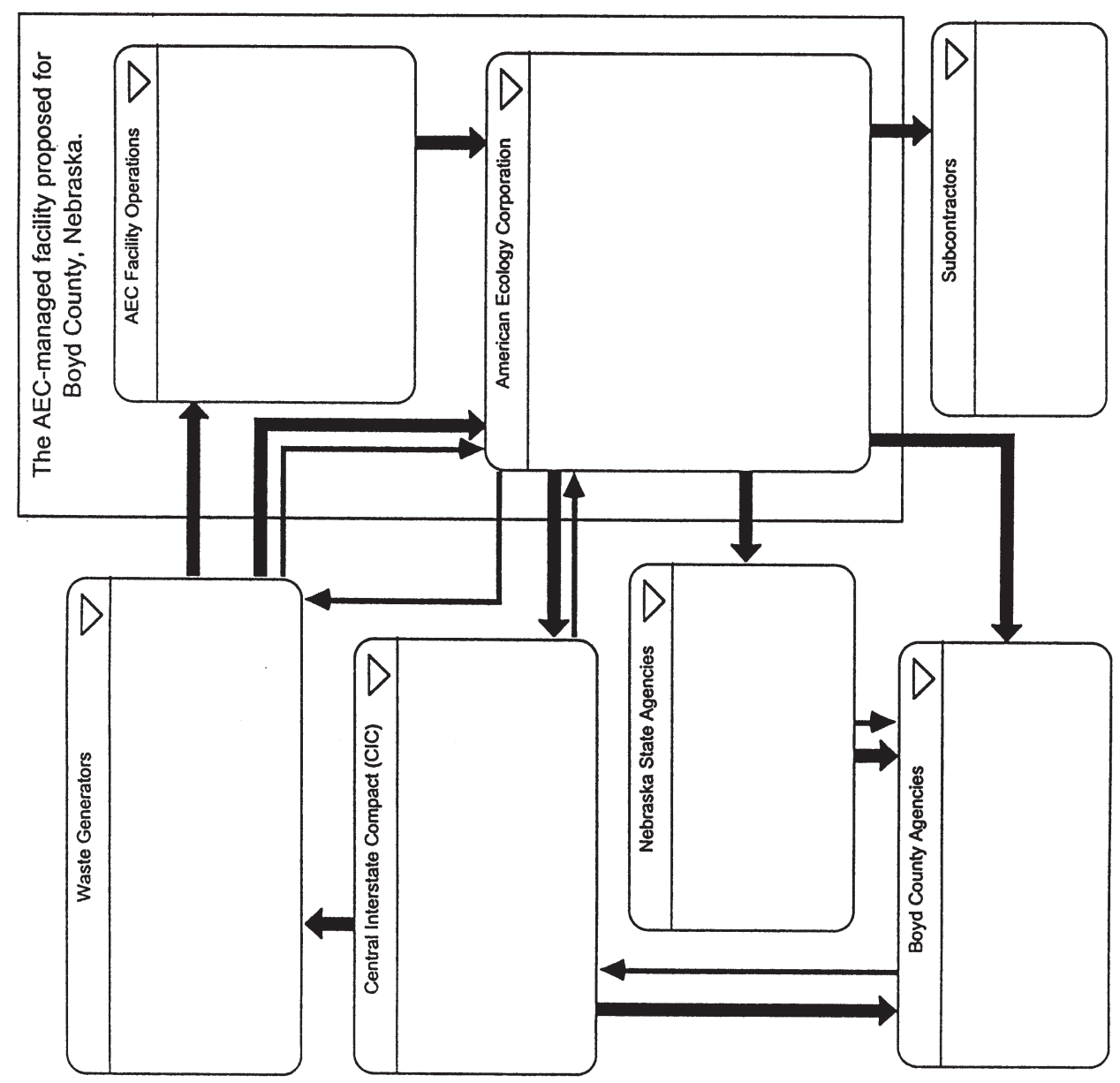

Figure 7. High level mapping of CIC network structure 


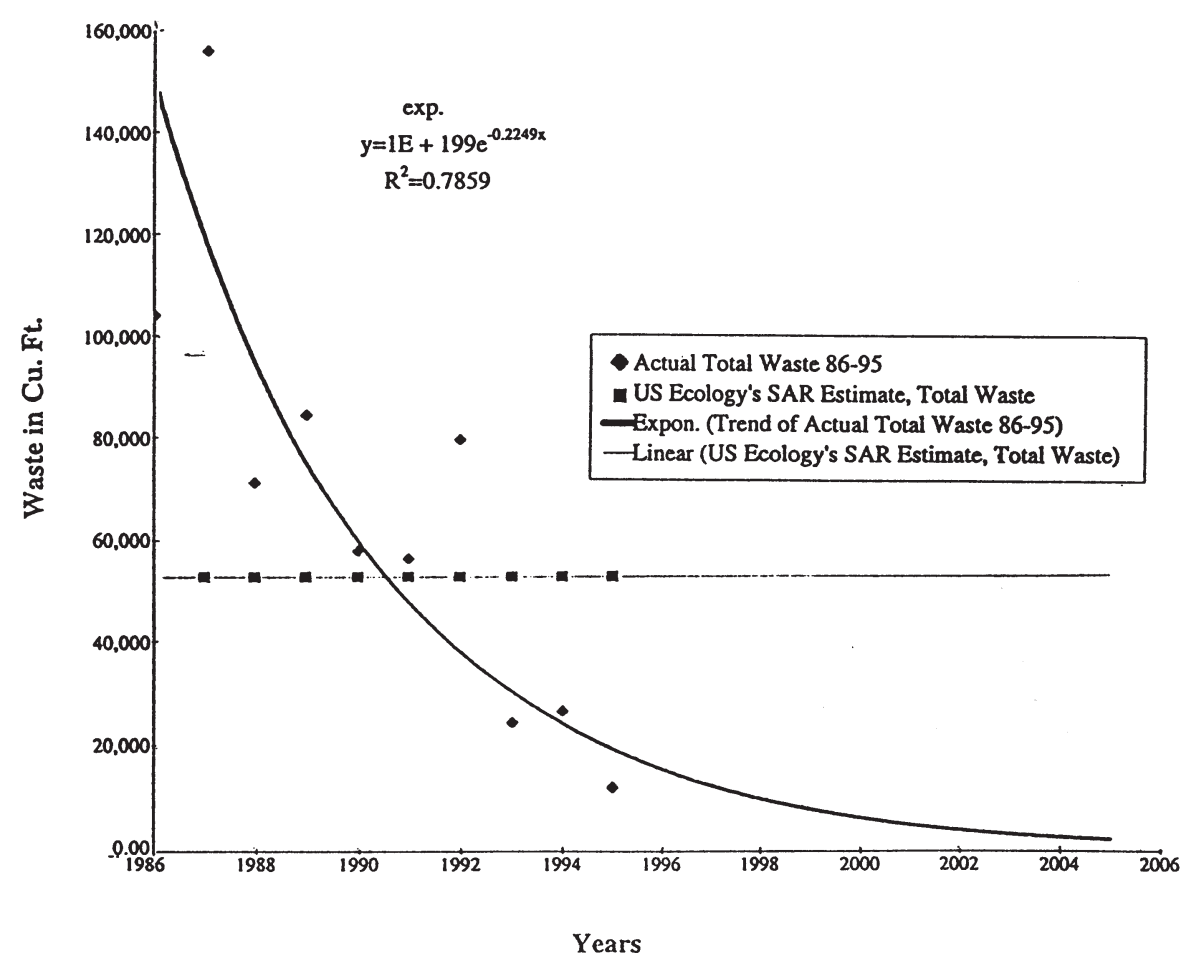

Figure 8. Total radioactive waste/low ofCIC states

The heavy lines in Figure 7 indicate the general flows among sectors; the thinner lines represent deliveries of rules, regulations, or criteria. Articulation of the sectors will begin with an explanation of the radioactive waste stream delivered from the generators to the AEC facility.

\section{Waste Stream}

As has been confirmed by numerous studies, the annual level of low- level radioactive waste continues to fall in the five-state region of the CIC and in the United States since 1980 (Coates, Heid, and Munger, 1994; Hoffman and Hayden, 1996; Chem-Nuclear, 1997; and Fuchs, 1996). Figure 8 is a summary of the waste flow in 
the CIC area since 1986. As is evident, total waste fell from a high in 1986 to a level of approximately 12,000 cubic feet in 1995. Statistical projections and technological assessments by nuclear engineers and economists predict the waste stream to continue to decrease.

The dramatic decrease in the waste stream is due to the development of new processes and the application of new technology. The history of low-level waste generation and disposal is one of increasing public concern for safer storage and disposal. Reconstructed, improved, and more secure facilities resulted in increased disposal fees charged to waste generators. In turn, generators responded to the increased fees by finding new ways to decrease the volume of waste through innovations in production technology and in compaction of waste generated (Jackson, 1996). As the volume of waste generated diminished, fewer units of waste were available over which to spread disposal facilities' overhead costs. Consequently, unit costs increased, providing generators further incentive to reduce waste volume still more. As will be discussed below, the combination of declining waste volume, increasing facility costs, and the contractual requirement that disposal fees be sufficient to cover unit costs has resulted in estimated disposal fees for the CIC facility much higher than industry norms. Furthermore, the cycle of innovation creates a problem with regard to the SAR that assumed a constant annual 55,000 cubic feet stream of waste (see Figure 8). A review of the waste stream of 5,000 cubic feet per year is a sound assumption for modeling purposes, erring on the side of adequacy. Thus, in Figure 9, the waste stream from the Waste Generators sector is 5,000 cubic feet per year. This reduction is waste volume calls for a reduction in the facility construction scenario, as will be discussed below.

\section{Pre-operational Debt Owed to Major Generators}

As explained above, the total principal and interest that accrued during the pre-operational phase to pay project expenses, is to be amortized and paid from waste stream charges. The major generators have been financing the payments of non-construc- 


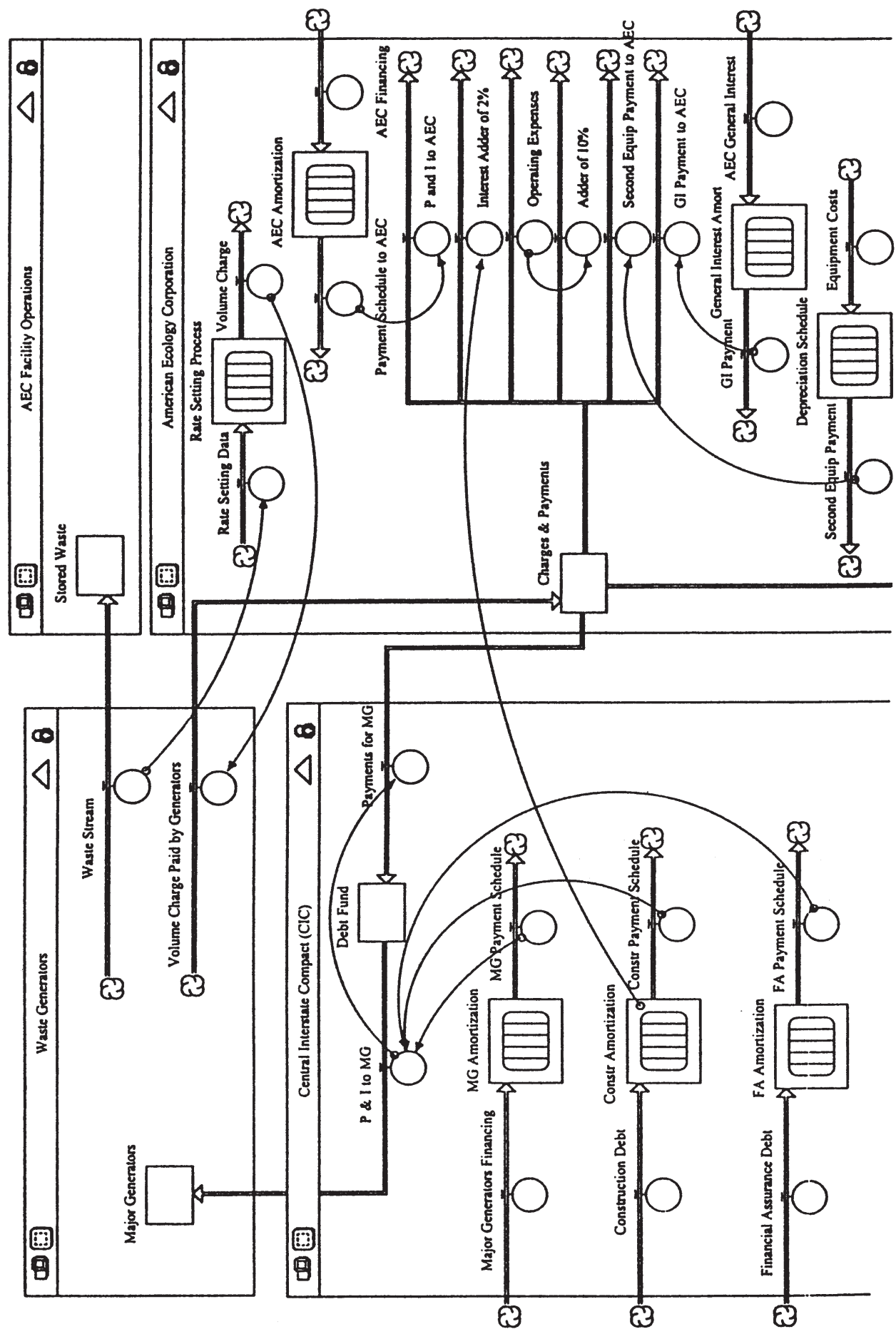

Figure 9. CIC operational cost network 


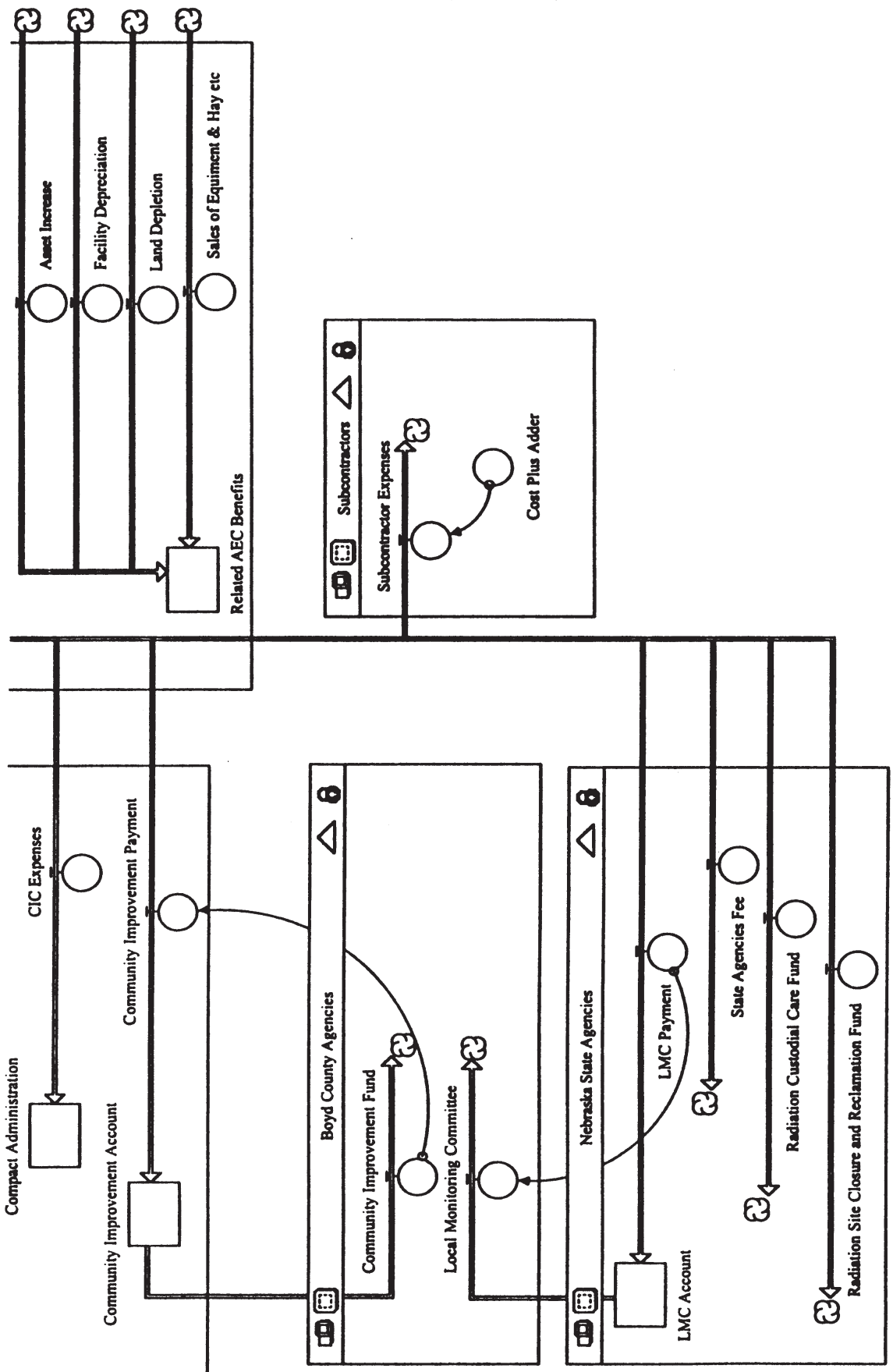

Figure 9. CIC operational cost network (continued) 
tion expenses during pre- operation with a cost-plus interest rate of prime plus 6.5 percent. The financing plus accrued interest will equal approximately $\$ 325$ million at the end of 2001 and then becomes the new principle for amortization. It is delivered to the CIC, as demonstrated in Figure 9. It is delivered to the doublelined rectangle labeled, Major Generators Amortization, interest since 1987 and will continue to receive such interest until operations begin in 2002. The interest rate was 20 percent until December 31,1996. At that date, the original principal of $\$ 6.2$ million.

According to the Agreement, the loan is to be amortized at an interest rate of prime plus 6.5 percent. The prime rate for the past thirty years has averaged about 9 percent, thus, consistent with the SAR, 9 percent is used as the prime rate. The double-lined rectangle is used to indicate that a programming sub-model is being used to transform a delivery in some way. A sub-model, which is a transformation processing station, usually represents an institutional component or components that have the responsibility and/or authority to apply the requisite rules, regulations, and their coefficients to the original delivery. The sub- model for the major generators financing is found in Appendix A. As is evident upon inspection, it is a standard amortization routine. In this case, it is utilized to determine the yearly payment to amortize the major generators* loan according to the requirements of the Agreement. (Subsequent amortization submodels are similar to the one presented in Appendix A.)

After the transformation process, the information about the yearly payments is delivered as MG Payment Schedule (Figure 9). The regulator then delivers those instructions, by the arc, to the regulator on the P and I to MG flow. This informs AEC (Figure 9) about the size, of the payment to be made each year to amortize this debt. The loan of $\$ 325$ million is amortized at a rate of 15.5 percent with level payments for thirty years using the amortization function from Appendix A. The annual payment to be collected for the loan is about $\$ 51$ million. The flow lines from AEC charges and payments to the CIC Debt Fund and then from the CIC Debt Fund to the Major Generators (Figure 9) indicate the yearly flow of the loan payment. The loan payment for each of the thirty years is found on row 30 of Table 3 According to the Agreement, any year in which that payment is not made, the unpaid amount is added to the remaining 
principle and the begins to accrue interest at prime plus 6.5 percent.

\section{AEC Contribution to Financing Pre-operational Expenses}

As explained above, a contribution was made by AEC for the financing of pre-operational expenses. This began in 1987 and reached the full contribution of $\$ 6.2$ million in 1991. This amount has been accruing plus accrued compound interest had grown to \$21.4 million. From January 1, 1997 until October 30, 1997, the interest rate is to be prime plus 3 percent. From then until December 31,2001 the interest rate is to be equal to prime. The total that will be owed to AEC on January 1, 1997 will be approximately $\$ 33.4$ million. According to the third amendment to the Contract, that amount is to be delivered to the operational phase, amortized, and repaid from surcharges on the disposal fees. As demonstrated in Figure 9, the AEC financing total is delivered to the AEC Amortization sub-model. The sub-model then delivers to the AEC Payment Schedule instructions to the P and I flow to AEC. The loan is amortized at an interest rate of prime plus 2 percent, or 11 percent, which results in level payments of $\$ 4.1$ million for the thirty-year life of the facility (see Table 3, row 31).

\section{Construction Loan}

Construction is to be completed by Bechtel. The plan in the SAR was for the facility to be constructed in three phases. However, due to the decrease in the amount of waste generated in the region, the first construction phase is all that will be considered in our analysis. The construction phase to be completed during the two-year period prior to operations provides for sufficient capacity. Its costs and the loan arrangement are determined according to the SAR, the 1997 Pre- construction Plan, and the Contract. The total includes a 5 percent adder paid to AEC for the construction work completed by Bechtel, and interest that accrues on the loan during construction. The total to be amortized is $\$ 91.6$ million.

Because of the destitute financial condition of AEC, it is assumed that the funds for the construction loan will also come from the major generators. As was the case for the pre-operation loan, 
Table 3. Total costs during operational phase, 2002 through 2031*

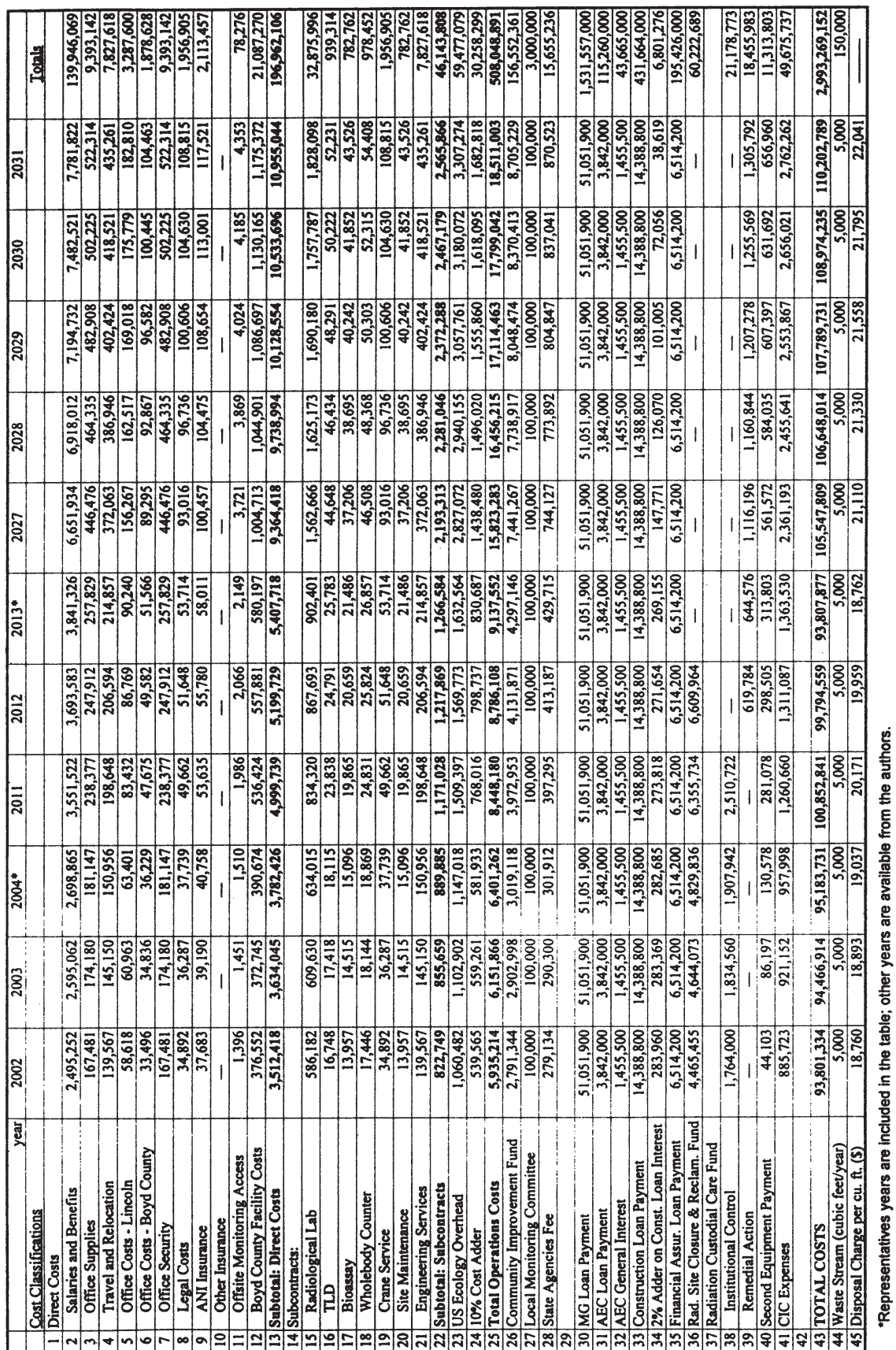


the CIC will serve as a conduit; borrowing from the major generators and loaning to AEC. Consistent with other funds borrowed from the major generators, the interest rate is expected to be prime plus 6.5 percent, or 15.5 percent. The construction loan is delivered to the CIC via the Construction Loan sub-model in Figure 9 for amortization calculations.

In addition to the construction loan being amortized over thirty years an adder of "an amount equal to two percent (2\%) of the interest portion of said payments ..." (Contract; 3rd Amendment 9, (6.01) a.4) is to be paid to AEC. The sub-model delivers the instructions for the annual loan payment to the CIC and the 2 percent adder to AEC (row 5, 33 and 34 of Table 3).

As indicated in Figure 9, the debt created by the financial assurance loan is delivered, via another amortization sub-model, to the CIC for collection. The FA Amortization sub-model (Appendix D) determines the yearly payments and delivers notice of that information to AEC, in Figure 9, for repayment. The yearly payment is reported in row 35 of Table 3 as about $\$ 6.5$ million.

\section{AECs General Interest Expenses}

AEC has reported in their SEC 10-K Report that they are capitalizing interest expenses incurred by their corporation in general, as part of the development costs of their projects in Boyd County, Nebraska and Ward Valley, California. None of this interest was incurred for the CIC project in Boyd County because all costs have been reimbursed including land and equipment costs. Only one of AECs subsidiaries, US Ecology, is involved in the CIC project. The interest that is being capitalized on the Boyd County project is related to borrowing under the Company's credit agreement with its bank lender in an attempt to keep AEC out of bankruptcy. AEC expects the capitalized interest, none of which was incurred for the Boyd County project, to be included in the rate base charged waste depositors as indicated in Figure 9. This General AEC Interest flow is delivered from outside the operational phase to the General Interest Amortization sub-model for calculation of the yearly payment. An average of the past two years was used as the expected 
added capitalization for each of the years during 1997 through 2001. One-half was allocated to Ward Valley and one-half to the CIC project. This made for a total of about $\$ 12.7$ million that will accumulate through 2001. Since other AEC contributions to be repaid are amortized at prime plus 2 percent, that rate (11 percent) is used for determining the loan payment schedule. The payment schedule is then conveyed to the payment process as indicated in Figure 9. The annual payment is about $\$ 1.4$ million, as reported in row 32 of Table 3.

\section{Operating Costs}

The costs explained above did not occur during the operational phase. Next, the costs that are to occur during the operational phase are discussed.

Direct Costs: The direct operating costs, along with their total are listed in rows 2 through 13 in Table 2 . They are taken directly from the SAR. The assumption of AEC, in the SAR is that direct costs will remain at the same level and mix throughout the thirtyyear period. Therefore, the only growth in those rows is a 4 percent annual increase due to inflation.

Of special interest is that the various direct-cost categories include equipment and small tools such as trucks, computers, office equipment, lab and calibration tools, and so forth. Therefore, this equipment is paid for in full when operating expenses are paid. The reason this is of special interest is because AEC is paid for this equipment a second time when AEC is paid an amount equal to the cost of small equipment according to what is called depreciation, as discussed below.

Subcontracts: The subcontractor's expenses during operation along with their total are found in rows 14 through 22 in Table 3, as reported in the SAR. The SAR explains that they are to be projected forward with an inflation rate of 4 percent.

AEC Overhead: An overhead charge of 42.5 percent of salaries and benefits is made by AEC. The annual payment to AEC is equal to the amounts found in row 23 of Table 3.

AEC adder of 10 Percent: AEC, according to the Contract, is to 
receive a 10 percent adder (row 24, Table 3) applied to the total of direct costs, subcontractor costs, and overhead; equal to the total of row 13 plus row 22 plus row 23.

As indicated in Figure 9, the total operating expenses are paid from charges on the waste stream and paid to AEC. These expenses are reported in row 25 of Table 3.

\section{Second Payment for Equipment and Tools}

According to the Contract, AEC is to be paid an amount equal to a depreciation schedule as applied to the full cost of equipment and tools bought during operation. So, in addition to using the depreciation as a tax deduction, AEC will get paid that amount. That means AEC is getting paid twice for the equipment and tools. For example, if a $\$ 25,000$ truck is bought, AEC gets paid $\$ 25,000$ immediately through reimbursement by the CIC. Then a five-year depreciation schedule is utilized as a means to get paid an additional $\$ 5,000$ per year for five years, or $\$ 25,000$. Moreover, AEC is allowed to retain the sale price of the truck when sold after it is five years old and to deduct the value of depreciation on its tax return.

The depreciation schedule utilized here assumes straight-line depreciation and a five-year useful life. The sub-model detailed to calculate the depreciation amount is shown in Appendix B. The delivery of the annual payment to AEC is indicated in Figure 9, and the total of this delivery is indicated in row 40 of Table 3.

\section{Nebraska State and Local Agencies}

As demonstrated in Figure 9, the facility is expected to generate funds for state and local agencies. One such fund is for community improvement in Boyd County, which is to paid to the CIC, which will, in turn, make equal payments to Boyd County. The total grows at 4 percent per year to cover inflation, as found in row 26 of Table 3. Another fund is established to support the Local Monitoring Committee (LMC). Its funding is a level $\$ 100,000$, without adjustment for inflation (row 27 of Table 3). It is paid by AEC to 
NDEQ, which in turn makes the payment to the LMC. Lastly, reimbursement of NDEQ expenses is represented as a delivery to Nebraska State Agencies. It is adjusted by 4 percent annually for inflation; (see row 28 of Table 3).

\section{Radiation Site Closure and Reclamation Fund and the Radiation Custodial Care Fund}

Nebraska law requires that funds be available for remedial, or corrective, action during the operational phase, and for site closure and stabilization after operations; a portion of these funds are initially front- loaded with monies from the financial assurance loan. The funds are collected as a surcharge on waste disposed at the facility. The Radiation Site Closure and Reclamation Fund (RSC\&R Fund) provides for site closure, while the Radiation Custodial Care Fund (RCC Fund) provides for both remedial action and long-term institutional care. Because of the reduced waste stream, figures reported in the SAR have been adjusted as discussed below.

Radiation Site Closure and Reclamation Fund: To accommodate the lower waste stream, a smaller facility than originally proposed will be sufficient. Therefore, a facility consistent with only the first phase of construction is assumed. The cost of closing a facility of this size, as estimated in the SAR, is accepted and then adjusted for inflation. This leaves about $\$ 60$ million to be collected via waste volume charges in the first eleven years. Consistent with the plan proposed in the SAR, the $\$ 60$ million is collected over years one through eleven of operations to satisfy the requirements of the RSC\&R Fund. This is indicated in row 36 of Table 3. Consistent with state guidelines that these funds be "outside the licensee's administrative control," Figure 9 represents payments for this fund as being delivered to the sector labeled Nebraska State Agencies.

Radiation Custodial Care Fund: The RCC Fund is administered in two components; remedial action and institutional care. As presented in the SAR, the necessary funds for remedial action are to be collected during years eleven through thirty. For institutional care, funds are collected in years one through ten. A portion of the financial assurance loan is targeted for the institutional care 
component of the RCC Fund. Consequently, given adjustments for inflation, for the smaller facility size, and for the diminished waste stream, about $\$ 21.2$ million is to be collected for institutional care, and about $\$ 18.4$ million will be collected for remedial action.

Table 3, rows 38 and 39, indicate the projected surcharges as required by Nebraska law. Similar to the delivery of the RSC\&R Fund, Figure 9c represents the RCC Fund payments as a delivery from AEC to the Nebraska State Agencies, consistent with NDEQ guidelines.

\section{The CIC Administrative Expenses}

The Contract provides that the CIC Commission may obtain funds from a surcharge to be levied on the users of the facility in order to pay the expenses of the Commission's administration of the Compact. Such charges have been represented in Figure 9. The administrative costs in 1996 were more than $\$ 700,000$. For calculations here, however, $\$ 700,000$ has been projected forward at an annual inflation rate of 4 percent. The payment amount is indicated in row 41 of Table 3.

\section{Related AEC Benefits}

Although not explicit in Figure 9, given the structure of the Contract, AEC can make a profit without the project being financially viable. AEC gets paid the adder equal to 2 percent of the interest owed on the construction loan, the adder of 10 percent of operating expenses, and gets paid twice for equipment and tools purchased. They can benefit as long as the major generators are willing to continue to finance losses even if there is no inflow of waste. The provisions of the Contract do not require that the facility have a positive cash flow before AEC can make a gain.

Other related benefits indicated in Figure 9 are as follows: the assets of AEC have been increased as the CIC pays for the land, equipment, and facility development and AEC takes ownership of the same. AEC has not had to pay interest on the asset gain. AEC, 
therefore, is receiving an implicit interest benefit. Since the facility has been given to AEC, it can be depreciated for tax deductions. The land value, according to AEC's SEC report, will be depleted for tax purposes Finally, the salvage value of equipment and other miscellaneous sales such as the hay crop, are also benefits to AEC. In addition, the Contract allows AEC any other income they might be able to get through the rate-making process. The provisions of the Contract do not require AECs gains be reduced if the facility is not financially successful.

\section{Financial Death Cycle}

As indicated in Figure 9, the Rate Setting Process sub-model (Appendix C) connects the payments to be made with the waste stream upon which the volume charges are to be assessed. The Contract provides that the disposal price is to be determined by dividing the costs by the amount of waste deposited at the facility. The results from those calculations are found in row 45 of Table 3. The charges necessary to cover contractual costs are greater than $\$ 18,500$ per cubic foot for every year. In comparison, Coates et al. found that for the compact system to work, charges could not be more than \$250 per cubic foot of waste (Coates, Heid and Munger, 1994). For private sector comparisons, Envirocare of Utah charges about $\$ 125$ per cubic foot for the lower spectrum of low-level radioactive waste. Chem-Nuclear Systems of South Carolina charges about $\$ 340$ for the full range of low-level radioactive waste. The Central Midwest Compact, made up of Illinois and Kentucky, estimated their expected operational costs to be $\$ 600$ per cubic foot and consequently decided the project was not financially viable. Thus, the estimated rates for the Boyd County facility indicate a death cycle-a financial death cycle.

The system is in a financial death cycle according to a two scenarios. The first is the economic character of demand, and the second concerns the exponential growth rate on unpaid loans. Knowledge of demand curves informs us that as prices are increased to try to cover exorbitant costs, the quantity of the good or service demanded decreases. If the decrease in quantity demanded is sub- 
stantial relative to the increase in price, then revenues decline. This is the case for monopolies because the elasticity of demand for monopolies is greater than unity for the relevant range of operation.

The AEC facility in Boyd County is a monopoly low-level radioactive waste facility. Given the cost situation that has been created by the $\mathrm{CIC}$, the unit price on waste deposited at the facility must be extremely high. This causes total revenue to fall, thus causing prices to be increased as required by the Contract, thus, causing revenues to fall further, and so forth. The facility, as indicated by the cost data in Table 3, is too expensive for use. To attempt to cover costs by raising disposal prices further contributes to a financial death cycle.

The second way in which the death cycle is manifested is through the expansion of costs as amortized loans are unpaid. Since the unit disposal price is too high to call forth sufficient revenues to cover costs, it will not be possible to meet scheduled principal and interest payments on loans. The unpaid portion will then be refinanced at the high interest that will further increase the payments to be made. However, this merely adds to the payment amount, previously not payable due to insufficient revenue. The debt continues to grow, contributing to the conditions of a financial death cycle.

\section{Concluding Remarks}

This SFM analysis has allowed us to observe the working of a corporate/government network, to confirm the validity of some well- known system principles, to discover new principles in a system network, to model operational costs of a particular case with the assistance of the system dynamics program ithink, and to thereby discover a financial death cycle that resulted when analysis and democracy have been excluded from policy and decision making.

One of the most important principles confirmed is the consequence of continuous circular cumulative causation whereby the feedback cycles of a system continue to reinforce each other, propelling a system farther and farther along a particular path as explained by Nobel prize economist, Gunmar Myrdal. When a system begins to deteriorate, the forces that are creating the de- 
terioration continue to re-circulate and accumulate greater and greater capacity for destruction. This happens because system provide feedback among the component parts such that any impact on a system which is inconsistent with the welfare of the system becomes magnified through the feedback process.

The CIC project is a refulgent example of the principle of continuous circular cumulative causation. Its basic contractual structure is designed to reinforce destructive characteristics. There are positive incentives to create high costs; to the high costs are added high cost-plus adders, to which high interest rates are then applied. All of these high costs require high waste-volume charges which will decrease use of the facility, which will then lead to accumulated high unpaid costs, which circle back through the system to make waste-volume charges increase further. This has continued to the point that the CIC project is not financially whole.

Closely related to continuous circular cumulative causation, and also confirmed, is the principle that positive feedback leads to growth and decay, while negative feedback is necessary for stability and sustainability. In the case studied here, the positive costplus incentives and interest adders encourage that energies and resources continue to be devoted to increasing costs, to the point the system is not financially viability. Negative incentives to encourage the reduction of cost functions, and penalties if performance milestones are not reached, are necessary to build a financial process that is sustainable, but are here absent.

The analysis of this corporate/government network confirms and magnifies the finding Henry Maine made late in the last century when he stated that the base of society had evolved from status to contract. The contractual element has grown in importance, and the battles over contractual form have a great influence on the working of the modern business and industrial process.

This study presents a new way to analyze the legal contracts that guide a system, a way that allows for connections to be made between contract provisions and the consequential flows and deliveries. Such an analysis becomes increasingly important as interest grows in monitoring costs of government contracts. Refined studies that uncover the direct and indirect consequences of particular contractual provisions can be made with the SFM analysis as was demonstrated with the analysis of the CIC pre- 
operational phase. Analyzing contracts is like eating bear meatthe more you chew the bigger it gets. Thus, an improved method for the analysis of contracts is a welcome addition to the social science tool kit.

We have also seen that social beliefs are not vague abstractions, but are criteria embedded in rules, regulations, requirements, as expressed and enforced in contractual obligations. Moreover, beliefs are divided and developed among a whole array of institutions and organizations, and refined by the institutional process throughout the network.

Policy scientists cannot determine efficiency criteria until social beliefs are known. This leads to the instrumentalist question: which belief components are appropriate to use in determining efficiency? In turn, this leads to the issue of social conflict and power. John R. Commons emphasized that the real social beliefs of a system are those that are enforced. This, he emphasized, determines reasonable value. His conclusion, is inadequate for a number of reasons. First, he was really stating, tautologically, that what exists is best. Second, in the case analyzed above, the enforced belief components led, not to reasonable consequences, but rather to a financial death cycle. Third, his prescription can be interpreted to mean that who ever has the power to establish and enforce the rules, regulations and requirements should be considered as enforcing efficiency and reasonable value. Such a prescription cannot be endorsed by instrumentalists. Those who have the power may enforce a system that is quite inconsistent with general social beliefs. Therefore, policy scientists can not avoid the issue of power and social conflict when evaluating for efficiency.

The system analyzed above functions the way it does because particular groups had the power to establish and enforce particular social rules and requirements that led to socially undesirable consequences. For example, when the two-to-three hundred percent cost-plus adders were established and enforced in the pre-operation phase Contract formulae, the operational phase was predestined for failure. The positive feedback was established within a swirl of social conflict manifested through political and judicial battles. The SFM analysis of networks allows for the tracing of connections between system components and system consequences. This allows for instrumental decisions about system efficiency. It 
also allows for the observation of socioeconomic power at work.

Policy studies have generated numerous hypotheses about social conflict, especially with respect to alliances among corporate interests and government. But such hypothesis are seldom modeled or explained with real-world examples. The SFM and ithink analysis allows for explicit modeling of a real world example and generates information about how those with power alliances have established a real-world network.

In addition, the computer model developed for this case can be utilized for future analysis and deliberations. It allows for the determination of impacts throughout the system to be measured when particular changes are contemplated. Thus, the impacts of alternative provisions in the Contract and the Agreement can be traced throughout the model. New sectors and new concerns can be added. For example, new engineering designs can also be used to help discover the systems that are viable.

\section{References}

Antonucci, G. 1997. Pre-requisites for a Stable Disposal Future at Barnwell. Presented to the Low-Level Waste Forum. Chem-Nuclear System.

Arnold, T. 1937. The Folklore of Capitalism. New Haven: Yale University Press.

Coates, D., V. Heid, and M. Munger 1994. "Not Equitable, Not Efficient: US Policy on Low-Level Radioactive Waste Disposal," Journal of Policy Analysis and Management, 13, No. 3, 526-538.

Fuchs, R. L. 1996. State-by-State Assessment of Low Level Radioactive Waste Received at Communal Disposal Sites. DOE/LLW-237. Washington, DC: US Department of Energy.

Groenewegen, J. and P. Beije 1989. “The French Communication Industry Defined and Analyzed Through the Social Fabric Matrix, the Filière Approach, and Network Analysis," Journal of Economic Issues 23 (December 1989), 1059-1974.

Gill, R. 1996. “An Integrated Social Fabric Matrix/Systems Dynamics Approach to Policy Analysis," System Dynamics Review 
12 (Fall 1996), 167-249.

Hayden, F. G. 1982. "Social Fabric Matrix: From Perspectives to Analytical Tool," Journal of Economic Issues 16 (September 1982), 637-661.

1988. "Values Beliefs, and Attitudes in a Sociotechnical Setting," Journal of Economic Issues, 22 (June 1988), 415-426.

1989. Survey of Methodologies for Valuing Externalities and Public Goods. Washington DC: US Environmental Protection Agency.

1996. "Report on the Financial Condition of American Ecology Corporation." Lincoln, NE: Office of the Nebraska Commissioner, Central Interstate Low-Level Radioactive Waste Compact.

1998. "Normative Analysis of Instituted Processes." In

Institutional Theory and Applications: Essays in Honour of Paul Dale Bush, S. Fayazmanesh and M. R. Tool eds. Cheltenham: Edward Elgar Publishing Ltd.

Hayden, F. G. and S. R. Bolduc 1997. "Political and Economic Analysis of Low-Level Radioactive Waste," Journal of Economic Issues 31 (June 1997), 605-613.

Hoffman, D. J. and F. G. Hayden 1996. “Waste Stream Analysis of the Proposal Low-Level Radioactive Waste Site in Boyd County, Nebraska." Lincoln, NE: Office of the Nebraska Commissioner, Central Interstate Low-Level Radioactive Waste Compact.

Jackson, S. A. 1997. LLWnotes. Washington DC: Afton Associates Inc. 11, June.

Kuzelka, R. 1996. "American Ecology Financial Information," Memo to F. Gregory Hayden, Lincoln Nebraska: Central Interstate Low-Level Radioactive Waste Commission, September.

Memo to F. Gregory Hayden, Lincoln Nebraska: Central Interstate Low-Level Radioactive Waste Commission, November.

Maine, H. S. 1861 (1986). Ancient Law: Its Connection with the Early History of Society and its Relation to Modern Ideas. New York: 
Dorset Press.

McCartney, L. 1988. Friends in High Places: The Most Secret Corporation and How It Engineered the World. New York: Simon \& Schuster.

Meister, B. 1990. "Analysis of the Federal Farm Policy Using the Social Fabric Matrix," Journal of Economic Issues 24 (March 1990), 189-224.

Melman, S. 1983. Profits Without Production. New York: Knopf.

Nebraska Department of Environmental Quality. Title 194-Rules and Regulations for the Disposal of Low-Level Radioactive Waste.

Nebraska Department of Health. Title 180, Nebraska Administrative Code, Chapter 1-Regulations for the Control of Radiation.

Radzizki, M. J. 1980. “Institutional Dynamics, Deterministic Chaos, and Self-Organization Systems," Journal of Economic Issues 24 (March 1980), 57-102.

Radzizki, M. J. and J. D. Sterman 1994. "Evolutionary Economics and System Dynamics." In Evolutionary Concepts in Contemporary Economics, R. England ed.,Ann Arbor: University of Michigan Press, 61-89.

Safety Analysis Report (Rev. 8). License Application submitted by US Ecology to the Nebraska Department of Environmental Quality, Lincoln NE.

Technical Service Agreement Between US, Inc. and Bechtel National, Inc. For Engineering, Procurement, and Construction Management Services for the Central Interstate Low-Level Radioactive Waste Disposal Facility. Lincoln, Nebraska: Office of US Ecology, Inc. 
Appendix A. Amortization of Major Generators Financing Contributions

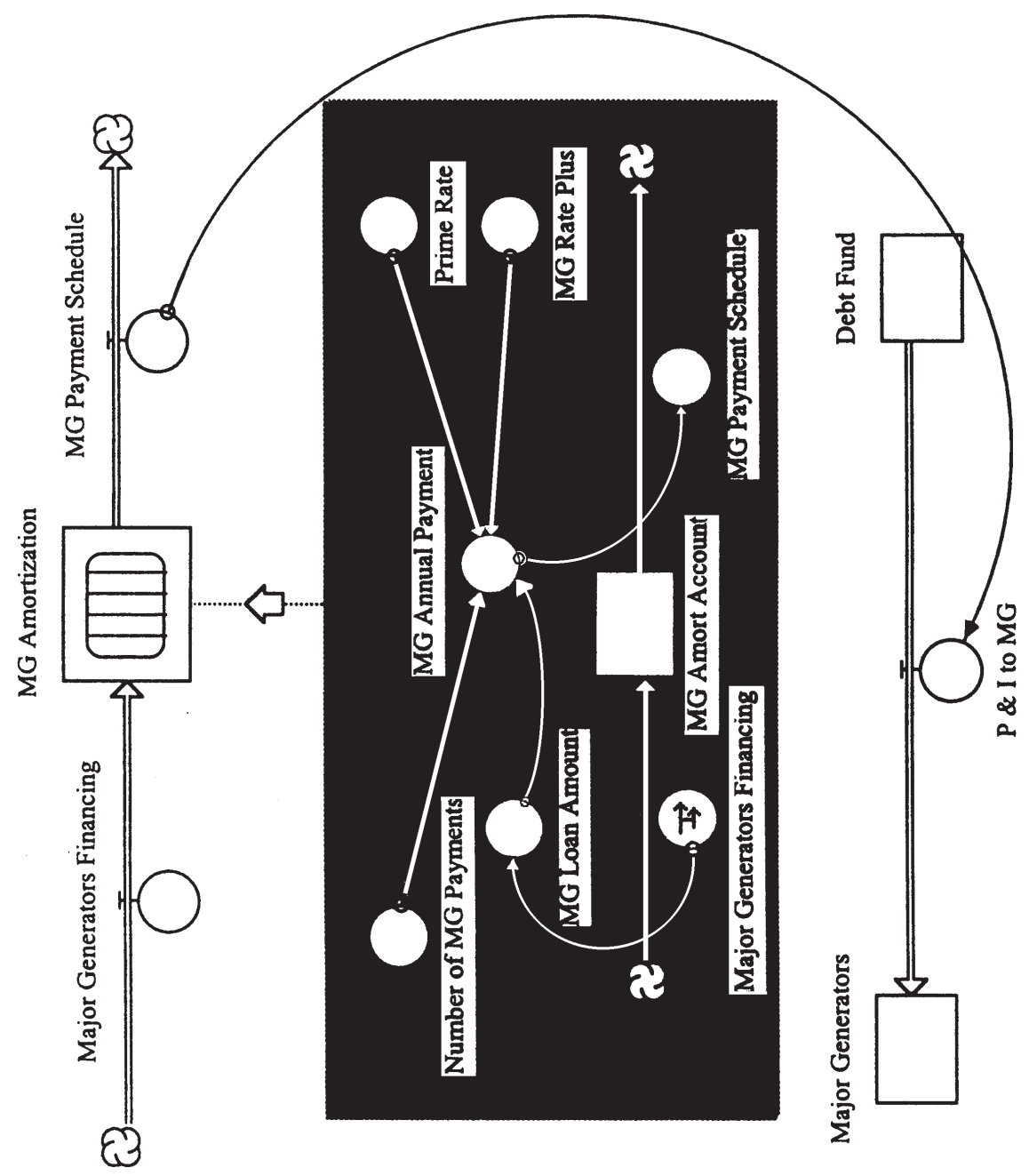


Appendix B. Depreciation Payment on Equipment

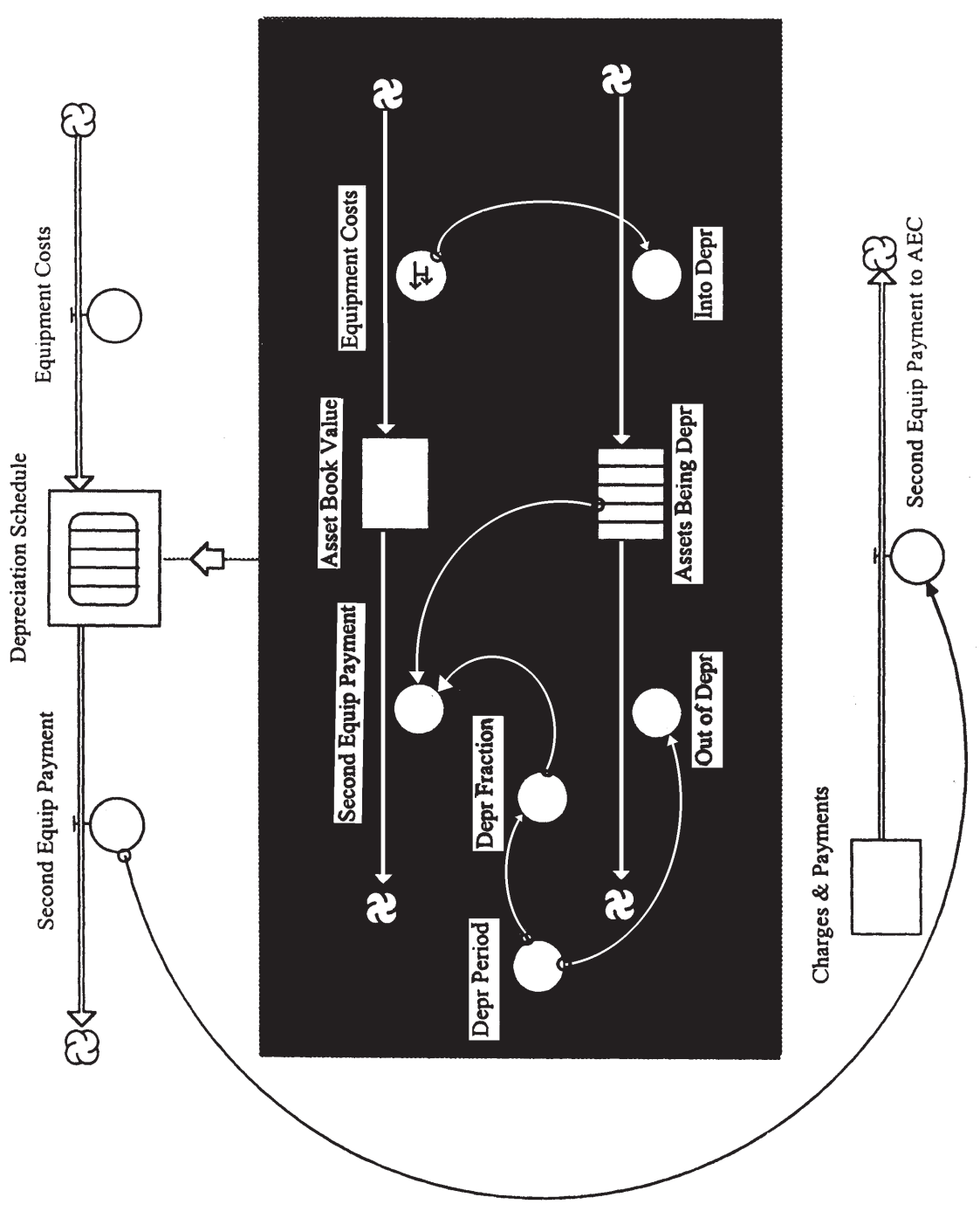




\section{Appendix C. Rate Setting Process}

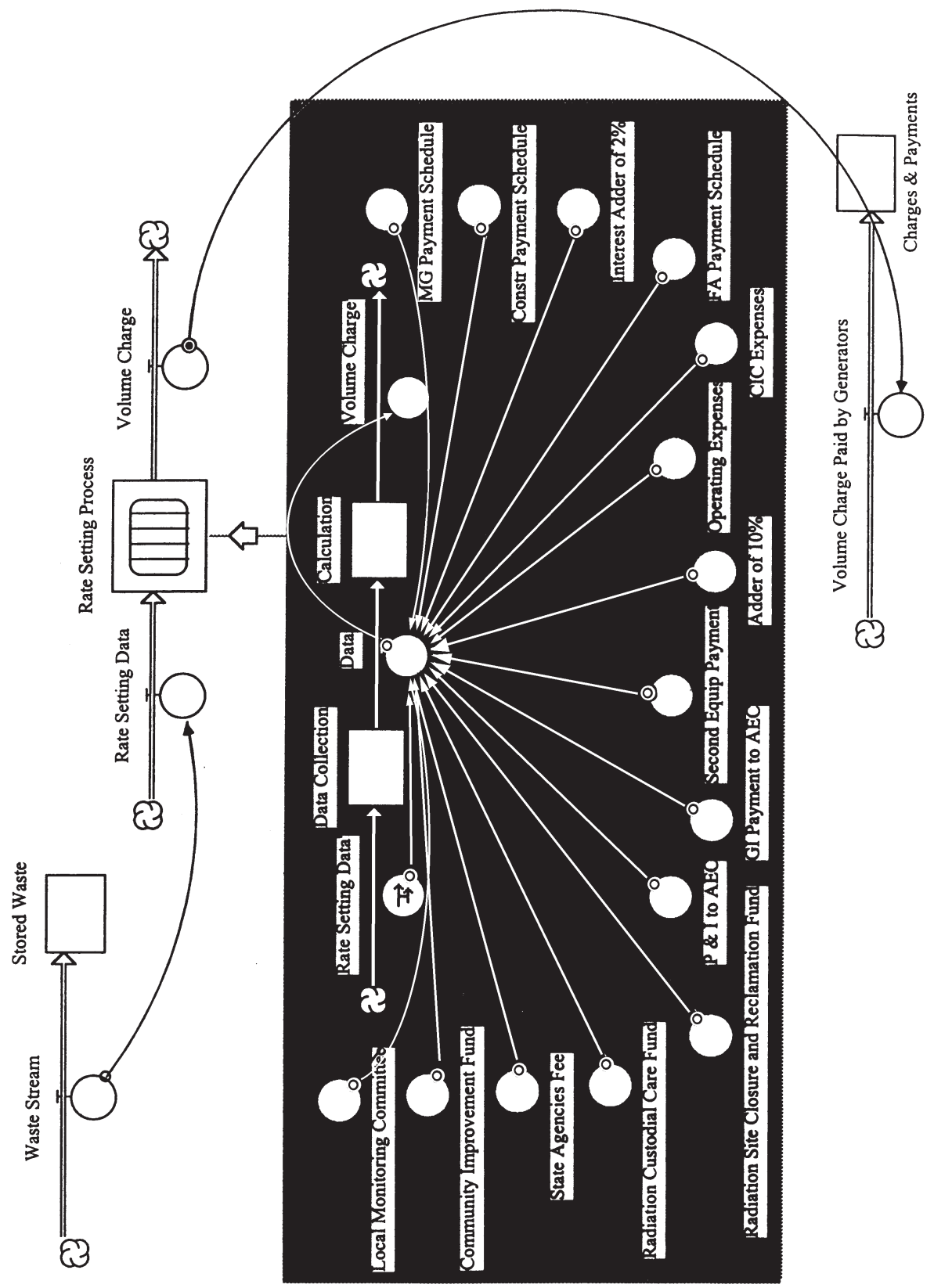




\section{Appendix D. Abbreviations and Symbols}

A through $\mathrm{N}$

AEC

Agreement

Bechtel

CIC

Contract

FA

GI

ithink ${ }^{\circledR}$

LMC

MG

NDEQ

RCC Fund

RCC\&R Fund

SAR

SEC

SFM

$P$ and I
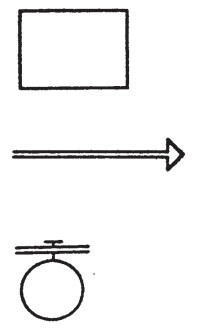

$\square$
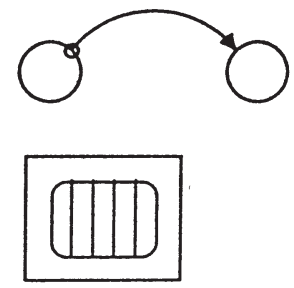

8
See Table 1

American Ecology Corporation

Contractual agreement between CIC and the major generators

Bechtel National, hie.

Central Interstate Low-Level Radioactive Waste Compact

Contractual agreement between CIC and AEC

Financial assurance

AEC general interest

Name of system dynamics computer program

Local Monitoring Committee of Boyd County, Nebraska

Major generators

Nebraska Department of Environmental Quality

Radiation Custodial Care Fund

Radiation Site Closure and Reclamation Fund

Safety Analysis Report

US Securities and Exchange Commission

Social Fabric Matrix

Principal and Interest

Institution or organization

Flow delivery

Regulator on a flow delivery

Rules, regulations, requirements, or criteria

Arc indicates delivery of rules, regulations, requirements, or criteria

Programming submodel, or a transformation process station

Source or destination of flow delivery not modeled in the system 